\title{
One-Pot Synthesis of Carbon Nanodots in an Organic Medium with Aggregation-Induced Emission Enhancement (AIEE): A Rationale for "Enzyme-Free" Detection of Cholesterol
}

Neelam Gogoi, ${ }^{\dagger, \S}$ Devesh S. Agarwal, ${ }^{\ddagger}, \S$ Aishwarya Sehgal, ${ }^{\ddagger}$ Devasish Chowdhury, ${ }^{* \dagger} \dagger$ and Rajeev Sakhuja ${ }^{\ddagger}$

${ }^{\dagger}$ Material Nanochemistry Laboratory, Physical Sciences Division, Institute of Advanced Study in Science and Technology, Garchuk, Guwahati 781035, Assam, India

${ }^{\ddagger}$ Department of Chemistry, Birla Institute of Technology \& Science, Pilani, Rajasthan 333031, India

Supporting Information

ABSTRACT: Addressing the limitations associated with the detection of cholesterol, we present a one-pot synthesis of a carbon nanodot $(\mathrm{CD})$ in an organic medium $\left(\mathrm{CD}_{\text {org }}\right)$ from a novel bile acid hydrazone-based organogel. Interestingly, $\mathrm{CD}_{\text {org }}$ possesses the aggregation-induced emission enhancement (AIEE) phenomenon, which rationally aids in the "enzyme-free" detection of cholesterol through a fluorescence turn-on mechanism. On dilution of the THF/water mixture of $\mathrm{CD}_{\text {org }}$ with its poor solvent (water), a 9.8-fold enhancement in its photoluminescence (PL) emission is witnessed. Such an enhancement in PL emission is credited to the occurrence of molecular restrictions due to the formation of nanoaggregates of $\mathrm{CD}_{\text {org }}$, thereby initiating a radiative pathway for exciton decay. Excitingly on adding cholesterol to $\mathrm{CD}_{\text {org }}$ we observed a similar enhancement in its PL emission without the use of any cholesterol oxidase $\left(\mathrm{ChO}_{x}\right)$ enzyme. The limit of detection and limit of quantification of cholesterol is found to be as low as 1.09 and $3.64 \mu \mathrm{M}$, respectively. Hence, this contribution highlights the enzyme-free fluorescence turn-on detection of cholesterol by a novel CD rationally designed to extend its applicability in an organic medium, where it is still considered a major restraint.

\section{INTRODUCTION}

Detection of cholesterol (a major component of the mammalian cell membrane) has always been an expensive task considering the crucial involvement of the cholesterol oxidase $\left(\mathrm{ChO}_{x}\right)$ enzyme to catalyze the oxidation of cholesterol to 4-cholesten-3-one and hydrogen peroxide. ${ }^{1-4}$ In addition to cost-ineffectiveness, $\mathrm{ChO}_{x}$ is prone to denaturation. Moreover, cholesterol is associated with solubility issues in an aqueous medium, limiting its detection to a great extent. Knowing the fact that a cholesterol concentration level higher than $5.17 \mathrm{mM}$ in the human blood ${ }^{1}$ may increase the risk for atherosclerosis, thrombosis, myocardial infarction, and many lipid-related ailments, regular monitoring of cholesterol in the blood is very crucial to human health. Therefore, a cost-effective, quick, easy to handle sensing probe for cholesterol is highly desirable.

In view of that, we present here a one-pot synthesis of fluorescent carbon nanodots (CDs) from a bile acid-based organogel in an organic medium $\left(\mathrm{CD}_{\text {org }}\right)$ to combat the aforementioned issues associated with the detection of cholesterol. This is the first report on the synthesis of fluorescent carbon nanoparticles of size less than $10 \mathrm{~nm}$ (CDs) using a bile acid hydrazone-based organogel as a precursor, clearly in contrast to previous reports of bigger carbon nanoparticles from an organogel..$^{5} \mathrm{CD}$, a zerodimensional carbogenic dot-nanoparticle, joined the versatile nanocarbon family after fullerene, carbon nanotubes, and graphene, since its inception by Sun et al. ${ }^{6}$ in 2006. Possessed by fascinating virtues, such as particle size less than $10 \mathrm{~nm}$, high chemical stability, low toxicity, and environmental threat, CD is regarded as a natural alternative to the conventional quantum dots (QDs), the fluorescent chalcogenide semiconductor nanocrystals. The literature has documented several applications of $\mathrm{CD}$, for instance, bioimaging, ${ }^{8,9}$ photocatalysis, ${ }^{10,11}$ light-emitting devices, ${ }^{12}$ sensing, ${ }^{13-18}$ and many more. In the last decade, great progress has been made in discovering different new precursors for the synthesis of CDs with unique functionalities. $^{6-15}$ These precursors, such as graphite oxide, candle soot, and activated carbon, have mostly carboxyl, hydroxyl, and amidogen functionalities that make CDs hydrophilic, regulating its easy dispersion in all aqueous

Received: May 22, 2017

Accepted: June 22, 2017

Published: July 24, 2017 
Scheme 1. Pictorial Representation of the Formation of Nanoaggregates of Organic CDs (OgTOam-CDorg) and Its Application as a Fluorescence Turn-On Sensor for Enzyme-Free Detection of Cholesterol

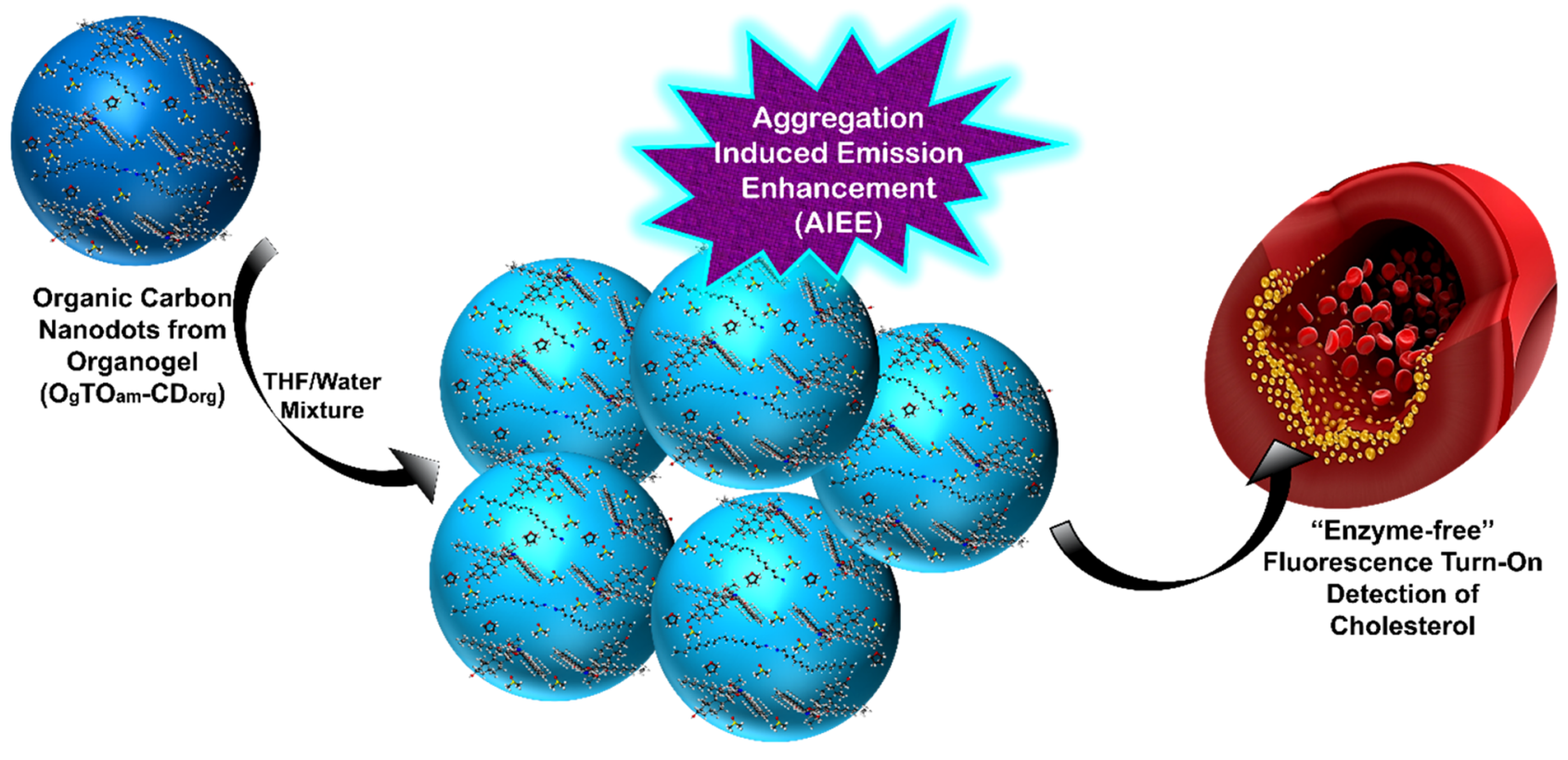

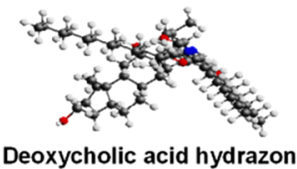

Deoxycholic acid hydrazone based compound

Nanoaggregates of $\mathrm{O}_{\mathrm{g}} \mathrm{TO} \mathrm{O}_{\mathrm{m}} \mathrm{CD}$ org
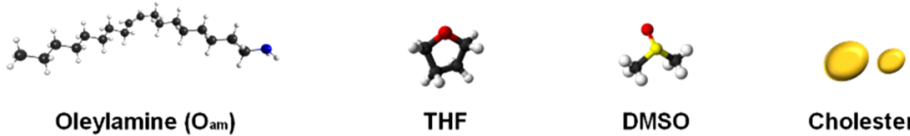

Cholesterol

solvents. Scientists have also tried to synthesize hetero-atom (sulfur/nitrogen) co-doped CDs from hair fibers as a precursor, as well as two-dimensional graphene QDs. ${ }^{19-21}$ On the one hand, these virtues have acted in favor of making $\mathrm{CD}$ an alternative to the conventional $\mathrm{QDs}^{7}$ in almost all application fields. On the other hand, the said hydrophilicity of CDs has limited its usage in the fields demanding organic medium, like oil-in-water separation, detection of nonaqueous soluble analytes, which necessitates the presence of active hydrophobic groups on the surface of CDs. There are very few reports on such $\mathrm{CD}$ systems having organosilane, $-\mathrm{CH}_{3}$, or long aliphatic carbon chains on their surfaces. ${ }^{22-24}$ However, none of these reports demonstrate exclusive synthesis of CDs detailing its application dedicated to the use of CDs in an organic medium. In addition, all these methods employ a very high reaction temperature $\left(200\right.$ to $\left.300{ }^{\circ} \mathrm{C}\right)$ and longer reaction times $(3-28$ h). For this reason, the problems in organic fields are still the same when it comes to the CD systems.

Taking clue from these literatures, we designed a simple onepot strategy to exclusively synthesize $\mathrm{CDs}$ in an organic medium $\left(\mathrm{CD}_{\text {org }}\right)$ from organogel $\left(\mathrm{O}_{\mathrm{g}}\right)$ in tetrahydrofuran (THF) in only $1 \mathrm{~h}$ at $100{ }^{\circ} \mathrm{C}$, relatively a much lower temperature. A novel deoxycholic acid-based hydrazone $((4 R)$ $N^{\prime}-((E)-3,4$ - bis (dodecyloxy) benzylidene ) - 4 $((3 R, 10 S, 12 S, 13 R)$-3,12-di-hydroxy-10,13-dimethyl-hexadecahydro- $1 H$-cyclopenta- $[a]$-phenanthren-17-yl)-pentane-hydrazide, Figure 10) synthesized in our laboratory was used as the organogelator in preparing $\mathrm{O}_{\mathrm{g}}$ for the study. Organogels, as the name suggests, are well-defined three-dimensional (3D) networks composed of similar helical, fibrous, or lamellar structures present in a hydrogel but can be prepared only through the gelation of organic solvents by means of various noncovalent interactions. ${ }^{25,26}$ Among numerous compounds investigated for organogel formation, the design of gelators based on bile acids remains a rational choice due to their detergent nature. Bile acids have a concave $\alpha$-face with multiple hydroxyl groups providing them with an amphiphilic nature that serves as a driving force for their self-assembly to act as a privileged scaffold for efficient organogelation. ${ }^{27}$ Reports on bile acid-based organogelators as a template for the synthesis of metal nanoparticles are scarce. ${ }^{28}$ Therefore, we have performed an exclusive study on the synthesis of bile acid-derived organogel-based fluorescent $\mathrm{CD}_{\text {org }}$ in THF and in other organic solvents.

Furthermore, $\mathrm{CD}_{\text {org }}$ was found to inherit the amazing aggregation-induced emission enhancement (AIEE) effect in a $\mathrm{THF} /$ water mixture (Scheme 1), thereby making it the first CD system to have shown this new-found "AIEE" phenomenon. ${ }^{29-33}$ We successfully fabricated this AIEE-active $\mathrm{CD}_{\text {org }}$ by using THF as the organic solvent and oleylamine $\left(\mathrm{O}_{\mathrm{am}}\right)$ as the surface passivation agent (Scheme 1). The as-prepared $\mathrm{O}_{\mathrm{g}} \mathrm{TO}_{\mathrm{am}}-\mathrm{CD}_{\text {org }}$ became nonemissive on dilution in THF, but emitted strongly in a 40/60 (v/v (\%)) THF/water mixture with a 9.8-fold enhancement in its PL intensity, which is discussed in detail in the Results and Discussion section. AIEE, a phenomenon quite opposite to the aggregation-caused quenching (ACQ) process, was first observed by Tang et al. ${ }^{34}$ in 2001. An AIEE system reportedly shows a huge enhancement in its PL emission intensity in the aggregated or solid state; however, it has very weak emission in a dilute solution state. Tang et al. ${ }^{34}$ observed this abnormal phenomenon in a silole-based organic material, following 

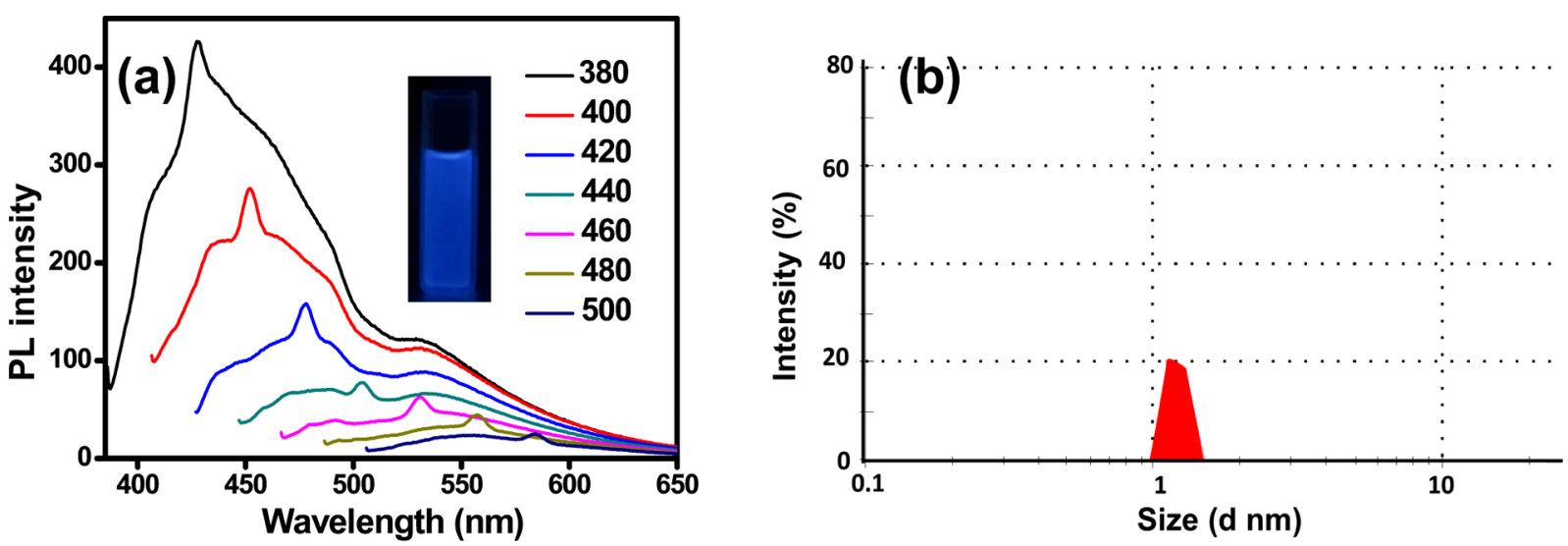

Figure 1. (a) Photoluminescence (PL) spectra of $\mathrm{O}_{\mathrm{g}} \mathrm{T}-\mathrm{CD}_{\text {org }}$ prepared from an $\mathrm{O}_{\mathrm{g}}$ organogel in THF. (Inset: The UV lamp image of the solution illuminated under $365 \mathrm{~nm}$.) (b) Dynamic light scattering (DLS) graph showing particle size distribution of $\mathrm{O}_{\mathrm{g}} \mathrm{T}-\mathrm{CD}_{\mathrm{org}}$.

which hundreds of reports confirmed this anti-ACQ phenomenon. ${ }^{35-40}$ The aggregates are in the nanoscale, which fluoresce brighter than their discrete parts, as per the collective quantityeffect rule. In principle, the active dynamic motions of molecules with the solvent media cause friction, transforming photonic energy to thermal energy resulting in the radiationless relaxation of excitons. Upon formation of nanoaggregates, these molecular motions get restricted, which activates the radiative channels for the decay of excitons, thus boosting their light emissions. A number of factors are found to be responsible for such restrictions, primarily, hindered intermolecular rotations in a molecule on aggregation.

Resolutely, we explored this AIEE attribute of the asprepared $\mathrm{O}_{\mathrm{g}} \mathrm{TO}_{\mathrm{am}}-\mathrm{CD}_{\text {org }}$ for an efficient " $\mathrm{ChO}_{x}$ enzyme-free" detection of cholesterol in the human blood serum through the fluorescence turn-on mechanism, a technique rather simple and easy in comparison to the already reported techniques. ${ }^{41}$ The limit of detection (LOD) and limit of quantification (LOQ) of cholesterol by $\mathrm{O}_{\mathrm{g}} \mathrm{TO}_{\mathrm{am}}-\mathrm{CD}_{\text {org }}$ were found to be as low as 1.09 and $3.64 \mu \mathrm{M}$, respectively. The chemistry between these molecules suggests that cholesterol molecules coaggregate on their addition to $\mathrm{O}_{\mathrm{g}} \mathrm{TO}_{\mathrm{am}}-\mathrm{CD}_{\mathrm{org}}$, resulting in a significant $\mathrm{PL}$ enhancement at $\lambda_{\max }=427 \mathrm{~nm}$. The applicability of $\mathrm{O}_{\mathrm{g}} \mathrm{TO}_{\mathrm{am}}{ }^{-}$ $\mathrm{CD}_{\text {org }}$ as a cholesterol sensor in the human blood serum was also tested, and it showed very convincing results without the use of any enzyme. This has made $\mathrm{O}_{\mathrm{g}} \mathrm{TO}_{\mathrm{am}}-\mathrm{CD}_{\text {org }}$ an AIEE phenomenon-based CD sensing probe for cholesterol, the only one of its kind to date. Therefore, this contribution is the first detailed successful demonstration of the synthesis of CDs in an organic medium from a bile acid-based organogel with the amazing new-found AIEE phenomenon for an enzyme-free detection of cholesterol through a fluorescence turn-on mechanism.

\section{RESULTS AND DISCUSSION}

Synthesis of Organogelator Deoxycholic Acid Hydrazone-Based Compound, 5d ((4R)- $N^{\prime}-((E)-3,4-B i s-$ (dodecyloxy)benzylidene)-4-((3R,10S,12S,13R)-3,12-dihydroxy-10,13-dimethylhexadecahydro- $1 \mathrm{H}$-cyclopenta[a]-phenanthren-17-yl)pentane-hydrazide). With an aim to prepare deoxycholic acid-based low-molecular-weight gelators, we initiated the synthesis by preparing a deoxycholyl hydrazide derivative (3) as the first precursor, ${ }^{42}$ starting from deoxycholic acid (1) via esterification, followed by hydrazination in ethanol. We then synthesized long-chain appended alkoxy aldehydes $(4 c-f)$ as the second precursors, by coupling commercially available hydroxyl aldehydes $(4 a-b)$ with bromoalkanes following a reported protocol. ${ }^{43}$ Finally, the coupling of 3 and 4 in ethanol under reflux conditions using acetic acid as a catalyst yielded long-chain appended deoxycholic acid-based hydrazones $(5 a-d)$ in good to excellent yield (Figure 10). All of the final compounds, $5 \mathrm{a}-\mathrm{d}$, were completely characterized on the basis of their detailed spectroscopic studies, such as ${ }^{1} \mathrm{H}$ and ${ }^{13} \mathrm{C}$ NMR, and the copies of ${ }^{1} \mathrm{H}$ and ${ }^{13} \mathrm{C}$ NMR spectra are included in the SI (5ad). Among $5 \mathrm{a}-\mathrm{d}, 5 \mathrm{~d}$ was used for the preparation of the organogel as a precursor of $\mathrm{CD}_{\text {org }}$ as it showed the best gelation property with stability at room temperature.

Synthesis and Characterization of Organic CDs $\left(C_{\text {org }}\right)$ from Organogel. Fluorescent organic $\mathrm{CDs}\left(\mathrm{CD}_{\text {org }}\right)$ possessing the active AIEE attribute were prepared from a novel organogel precursor. The organogel $\left(\mathrm{O}_{\mathrm{g}}\right)$ was prepared in DMSO from a novel deoxycholic acid hydrazone-based compound, 5d ((4R)-N'-((E)-3,4-bis (dodecyloxy)benzylidene)-4-((3R,10S,12S,13R)-3,12-dihydroxy-10,13-dimethylhexadecahydro- $1 H$-cyclopenta-[a]-phenanthren-17-yl)pentane-hydrazide), synthesized in our laboratory. The detailed reaction pathway followed for the synthesis of organogelator $5 \mathrm{~d}$ is shown in Figure 10. The organogel $\left(\mathrm{O}_{g}\right)$ which showed blue fluorescence under a UV lamp (365 nm) was deliberately investigated as a potential precursor for synthesizing CDs in an organic medium. Initially, $\mathrm{O}_{g}$ was refluxed in THF at an elevated temperature $\left(100^{\circ} \mathrm{C}\right)$. This solution with a weak blue fluorescence under the UV lamp (365 nm) showed excitationdependent PL emission when excited with $\lambda_{\text {ex }} \sim 380,400,420$, 440, 460, 480, and $500 \mathrm{~nm}$ (Figure 1a).

The native nature of a $\mathrm{CD}$ system, that is, a shift in the emission wavelength $\left(\lambda_{\mathrm{em}}\right)$ along with a decrease in the PL intensity with an increase in $\lambda_{\mathrm{ex}}$ was also evident. Thus, the solution was named as $\mathrm{O}_{\mathrm{g}} \mathrm{T}-\mathrm{CD}_{\text {org }}$. To study the effect of a solvent on the PL property of the $\mathrm{CD}_{\text {org }}$, a set of four other organic solvents were used to synthesize $\mathrm{CD}_{\text {org }}$ from $\mathrm{O}_{g}$, viz., toluene $(\mathrm{Tu}), n$-hexane $(\mathrm{Hx})$, acetonitrile $(\mathrm{An})$, and epichlorohydrin (Ech). The PL spectra of $\mathrm{CD}_{\text {org }}$ prepared in all these solvents were studied and is detailed in Figure S1 of SI. Of all of the five $C_{\text {org }}$ 's prepared in different solvents, $\mathrm{O}_{\mathrm{g}} \mathrm{T}-\mathrm{CD}_{\text {org }}$ showed the best PL property, suggesting the influential role of different solvents in tuning the PL property through the electronic construction of $\mathrm{CD}_{\text {org }}$. Considering the results obtained, $\mathrm{O}_{\mathrm{g}} \mathrm{T}-\mathrm{CD}_{\text {org }}$ was chosen as the organic $\mathrm{CD}$ of our 

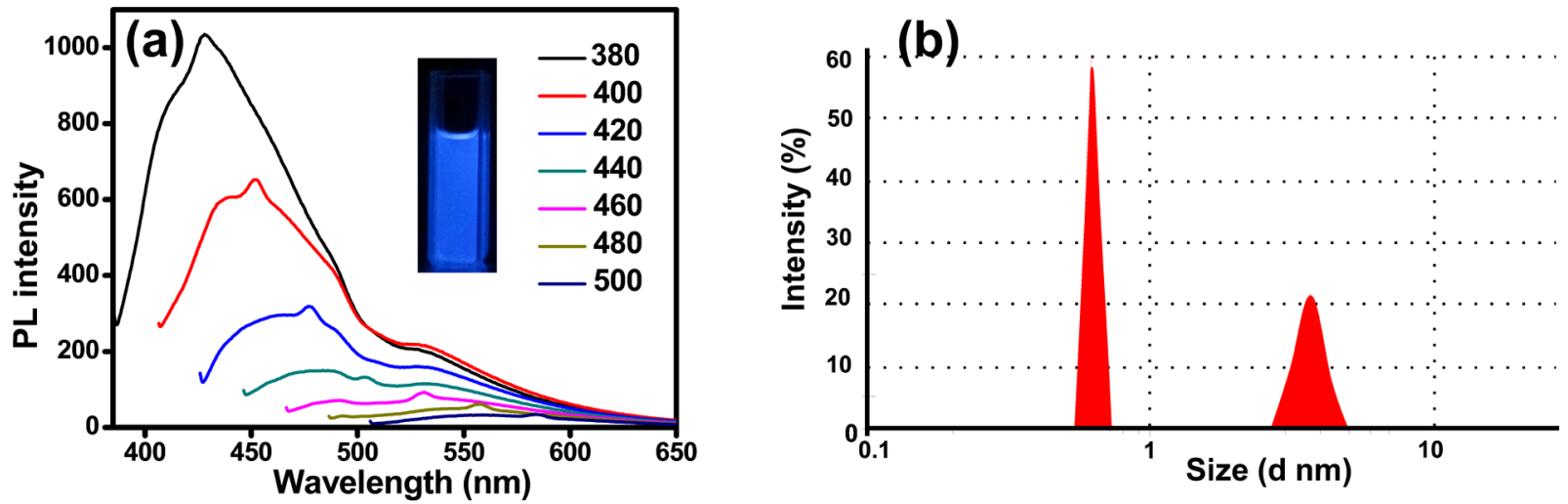

Figure 2. (a) PL spectra of $\mathrm{O}_{\mathrm{g}} \mathrm{TO}_{\mathrm{am}}-\mathrm{CD}_{\text {org }}$ prepared from $\mathrm{O}_{\mathrm{g}}$ (organogel) in a $\mathrm{THF} / \mathrm{O}_{\mathrm{am}}$ solution. (Inset: The UV lamp image of the solution illuminated under $365 \mathrm{~nm}$.) (b) DLS graph showing particle size distribution of $\mathrm{O}_{\mathrm{g}} \mathrm{TO}_{\mathrm{am}}-\mathrm{CD}_{\text {org. }}$.
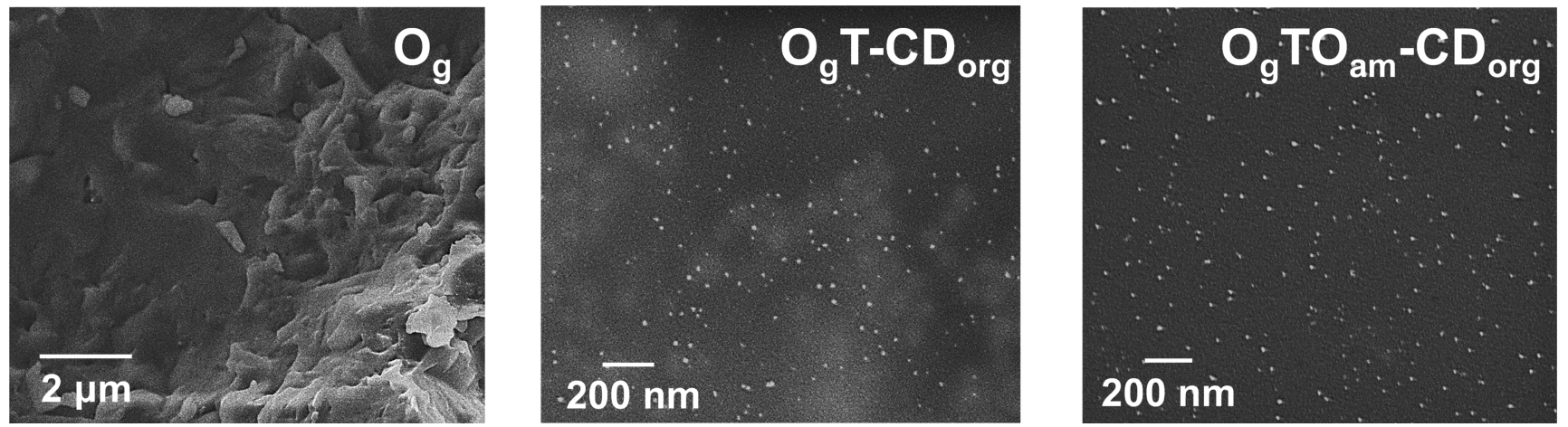

Figure 3. SEM images of the organogel $\left(\mathrm{O}_{\mathrm{g}}\right)$ and the organic CDs prepared in THF $\left(\mathrm{O}_{\mathrm{g}} \mathrm{T}-\mathrm{CD}_{\text {org }}\right)$ and $\mathrm{THF} / \mathrm{O}_{\mathrm{am}}\left(\mathrm{O}_{\mathrm{g}} \mathrm{TO}_{\mathrm{am}}-\mathrm{CD}_{\text {org }}\right)$.

interest for the complete study. We also checked the particle size of $\mathrm{O}_{\mathrm{g}} \mathrm{T}-\mathrm{CD}_{\text {org }}$ through the DLS analysis depicting sizes below $10 \mathrm{~nm}$ (Figure 1b), an important criterion of a CD system.

With an aim to enhance the PL intensity of a CD system, the incorporation of different compounds as a surface passivating agent has been experimented since the introduction of CDs by Sun et $\mathrm{al}^{6}{ }^{6}$ Therefore, in our organic carbon dot system $\left(\mathrm{O}_{\mathrm{g}} \mathrm{T}\right.$ $\mathrm{CD}_{\text {org }}$ ), the feasible role of any compound for surface passivation was studied. Oleylamine $\left(\mathrm{O}_{\mathrm{am}}\right)$ is famously known as a coordinating ligand for the synthesis of many nanoparticles. ${ }^{44}$ Its terminal $-\mathrm{NH}_{2}$ group makes it a perfect ligand for several metal-based nanosystems. Here, the novelty of $\mathrm{O}_{\mathrm{am}}$ in passivating the surface of an organic $\mathrm{CD}$ system was investigated. The $\mathrm{O}_{\mathrm{g}} \mathrm{TO}_{\mathrm{am}}-\mathrm{CD}_{\text {org }}$ was prepared by refluxing $\mathrm{O}_{\mathrm{g}}$ in a 9:1 ratio solution of $\mathrm{THF} / \mathrm{O}_{\mathrm{am}}$ at $100{ }^{\circ} \mathrm{C}$, and its $\mathrm{PL}$ emission was studied at $\lambda_{\text {ex }} \sim 380,400,420,440,460,480$, and $500 \mathrm{~nm}$ (Figure 2a). A noteworthy 2.4-fold enhancement in the $\mathrm{PL}$ intensity of $\mathrm{O}_{\mathrm{g}} \mathrm{TO}_{\mathrm{am}}-\mathrm{CD}_{\text {org }}$ confirmed the fact that the surface of $\mathrm{CD}_{\text {org }}$ was successfully passivated by the $\mathrm{O}_{\mathrm{am}}$ molecules. It should be noted that the passivation agent $\left(\mathrm{O}_{\mathrm{am}}\right)$ contains no chromophore and therefore the observed enhancement in PL must be attributable to the surface passivated $\mathrm{O}_{\mathrm{g}} \mathrm{TO}_{\mathrm{am}}-\mathrm{CD}_{\mathrm{org}}$. A DLS analysis to quantify the particle size of $\mathrm{O}_{\mathrm{g}} \mathrm{T}-\mathrm{CD}_{\text {org }}$ and $\mathrm{O}_{\mathrm{g}} \mathrm{TO}_{\mathrm{am}}-\mathrm{CD}_{\text {org }}$ was also performed. The presence of particles of sizes less than $10 \mathrm{~nm}$ in the DLS graph of both the $\mathrm{CD}_{\text {org }}$ systems (Figure $2 \mathrm{~b}$ ) satisfied this essential property of a CD system.

The investigation of any morphological change from a microscale in the organogel to a nanoscale in $\mathrm{CD}_{\text {org }}$ was done through scanning electron microscopy (SEM) imaging, as depicted in Figure 3. The freeze-dried organogel $\left(\mathrm{O}_{g}\right)$ showed a lamellar packing (fibrous network of microstructures), which changed to dotlike nanoparticles through a one-pot reflux in $\mathrm{THF}$ at elevated temperatures in $\mathrm{O}_{\mathrm{g}} \mathrm{T}-\mathrm{CD}_{\text {org }}$. Such type of morphological changes could be partially credited to a lowering in the surface free energy of the molecule in the gel-to-solution course of the reaction. After passivation with $\mathrm{O}_{\mathrm{am}}$, a uniform and dense distribution of the dotlike nanoparticles (size $\leq 10$ $\mathrm{nm}$ ) was observed in $\mathrm{O}_{\mathrm{g}} \mathrm{TO}_{\mathrm{am}}-\mathrm{CD}_{\mathrm{org}}$. In addition, an absence of precipitation from the $\mathrm{O}_{\mathrm{g}} \mathrm{TO}_{\mathrm{am}}-\mathrm{CD}_{\text {org }}$ suspension was noticed even after 6 months of its storage at $4{ }^{\circ} \mathrm{C}$, which reflected its outstanding colloidal stability. All of these analyses thereby validated that $\mathrm{O}_{\mathrm{am}}$ could be a prospective passivation agent in an organic $\mathrm{CD}$ system.

Following this, X-ray photoelectron spectroscopy (XPS) was employed to study the surface element composition of $\mathrm{O}_{\mathrm{g}} \mathrm{T}$ $\mathrm{CD}_{\text {org }}$ and $\mathrm{O}_{\mathrm{g}} \mathrm{TO}_{\mathrm{am}}-\mathrm{CD}_{\text {org. }}$. The findings so obtained (Figure $4 \mathrm{a}, \mathrm{b})$ showed three peaks typical of $\mathrm{C} 1 \mathrm{~s}$ at $285 \mathrm{eV}, \mathrm{N} 1 \mathrm{~s}$ at 400 $\mathrm{eV}$, and $\mathrm{O} 1 \mathrm{~s}$ at $531 \mathrm{eV}$. The content ratio of these peaks in $\mathrm{O}_{\mathrm{g}} \mathrm{TO}_{\mathrm{am}}-\mathrm{CD}_{\text {org }}$ was 92.02, 2.23, and $5.08 \%$, whereas in $\mathrm{O}_{\mathrm{g}} \mathrm{T}$ $\mathrm{CD}_{\text {org }}$ it was $93.52,1.52$, and $4.18 \%$, respectively. Clearly, a higher \% of nitrogen is indicative of the presence of oleylamine as the surface passivation agent in $\mathrm{O}_{\mathrm{g}} \mathrm{TO}_{\mathrm{am}}-\mathrm{CD}_{\text {org }}$. Furthermore, the high-resolution XPS spectra (Figure $4 c-h$ ) gave the information about the elemental states of all of the bands of $\mathrm{C} 1 \mathrm{~s}, \mathrm{~N} 1 \mathrm{~s}$, and $\mathrm{O} 1 \mathrm{~s}$ on deconvolution. $\mathrm{C} 1 \mathrm{~s}$ of $\mathrm{O}_{\mathrm{g}} \mathrm{TO}_{\mathrm{am}}-\mathrm{CD}_{\text {org }}$ could be deconvoluted into two peaks at $285.03 \mathrm{eV}$ assigned to $\mathrm{C}-\mathrm{C} / \mathrm{C}=\mathrm{C}$ and 284.23 assigned to $\mathrm{C}-\mathrm{O} / \mathrm{C}-\mathrm{N}$ groups present on the surface. In $\mathrm{O}_{\mathrm{g}} \mathrm{T}-\mathrm{CD}_{\mathrm{org}}$, two peaks at 285.15 $\mathrm{eV}(\mathrm{C}-\mathrm{OH} / \mathrm{C}-\mathrm{O}-\mathrm{C})$ and $284.67 \mathrm{eV}(\mathrm{C}=\mathrm{O})$ were obtained from its C 1s XPS band. Similarly, for the N 1s band of 

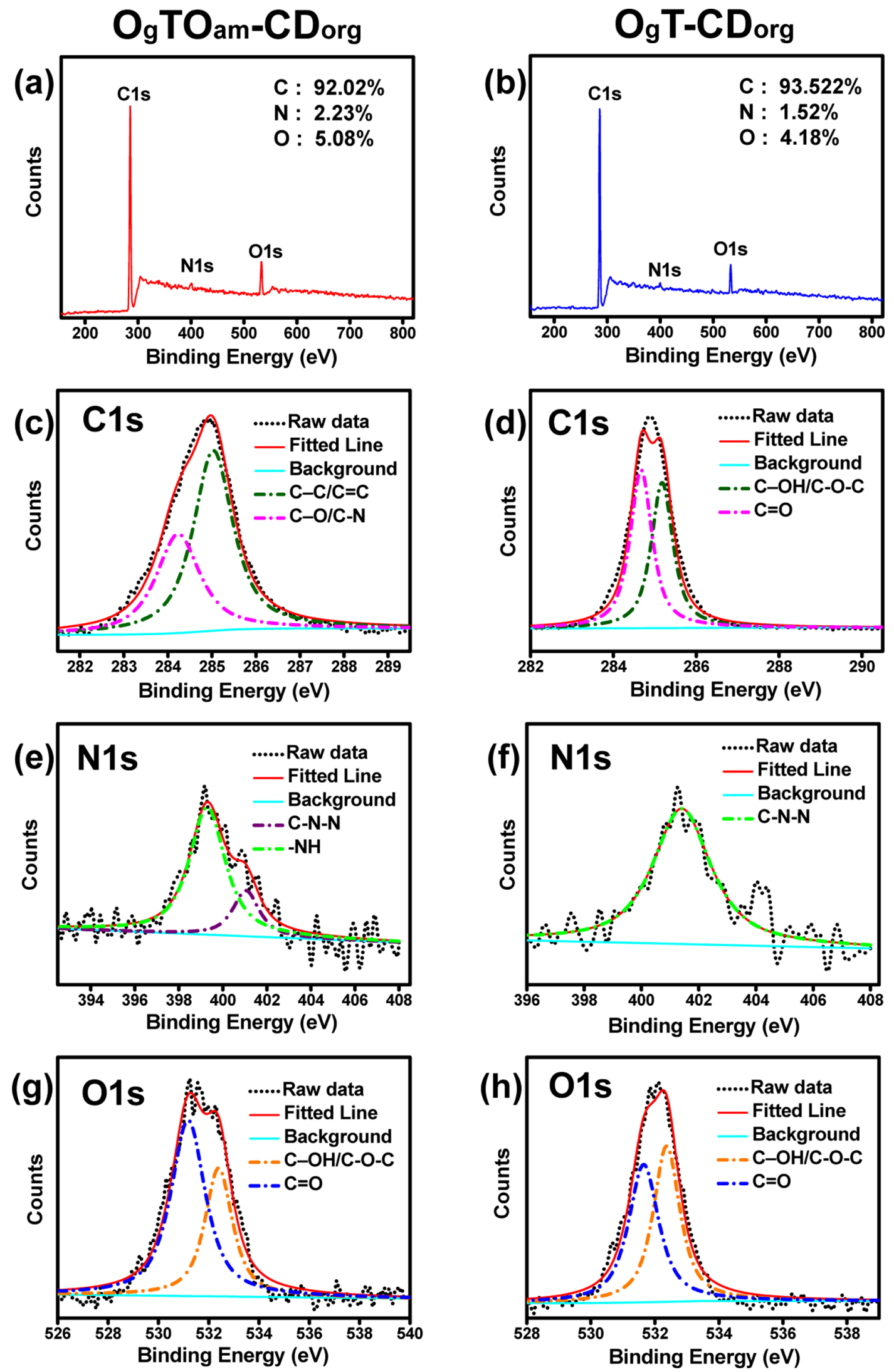

Figure 4. XPS full survey of (a) $\mathrm{O}_{\mathrm{g}} \mathrm{TO}_{\mathrm{am}}-\mathrm{CD}_{\text {org }}$ and (b) $\mathrm{O}_{\mathrm{g}} \mathrm{T}-\mathrm{CD}_{\mathrm{org}}$. High-resolution XPS C 1s spectra of (c) $\mathrm{O}_{\mathrm{g}} \mathrm{TO}_{\mathrm{am}}-\mathrm{CD}_{\mathrm{org}}$ and $(\mathrm{d}) \mathrm{O}_{\mathrm{g}} \mathrm{T}-\mathrm{CD}_{\mathrm{org}}$. High-resolution XPS N 1s spectra of (e) $\mathrm{O}_{\mathrm{g}} \mathrm{TO}_{\mathrm{am}}-\mathrm{CD}_{\text {org }}$ and (f) $\mathrm{O}_{\mathrm{g}} \mathrm{T}-\mathrm{CD}_{\text {org }}$. High-resolution XPS O 1s spectra of $(\mathrm{g}) \mathrm{O}_{\mathrm{g}} \mathrm{TO} \mathrm{O}_{\mathrm{am}}-\mathrm{CD}_{\mathrm{org}}$ and $(\mathrm{h}) \mathrm{O}_{\mathrm{g}} \mathrm{T}-$ $\mathrm{CD}_{\text {org }}$. Each band was deconvoluted following the literature. 


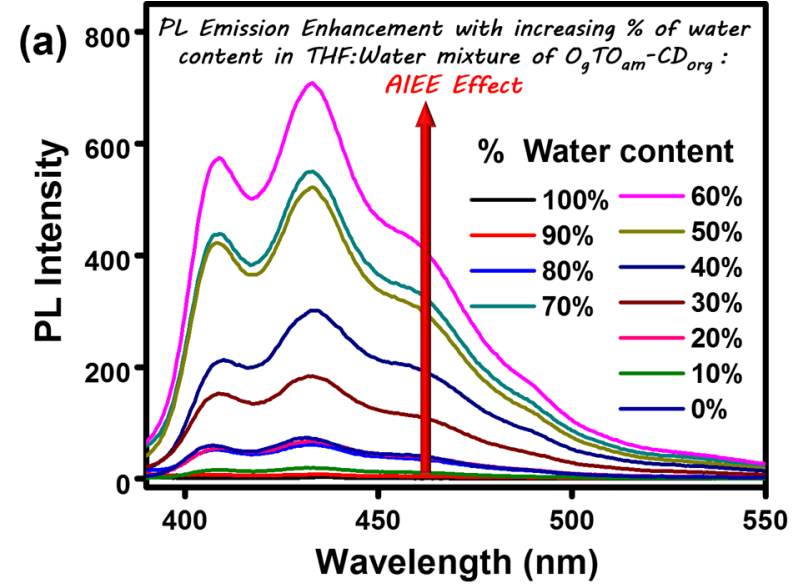

(b) Fluorescence images of THF: Water mixture of $\mathrm{O}_{\mathrm{g}} \mathrm{TO}_{\mathrm{am}}-\mathrm{CD}_{\text {org }}$ with increasing $\%$ of water content

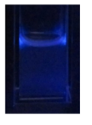

$10 \%$

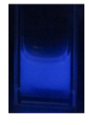

$20 \%$

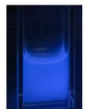

$70 \%$

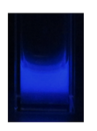

$30 \%$

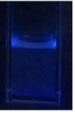

$80 \%$

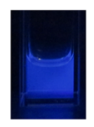

$40 \%$

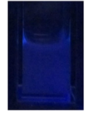

$90 \%$

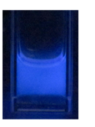

$50 \%$

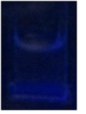

$100 \%$

(C) A plausible mechanism for PL emission enhancement in $\mathrm{O}_{\mathrm{g}} \mathrm{TO}_{\mathrm{am}}-\mathrm{CD}_{\text {org }}$ due to AIEE effect

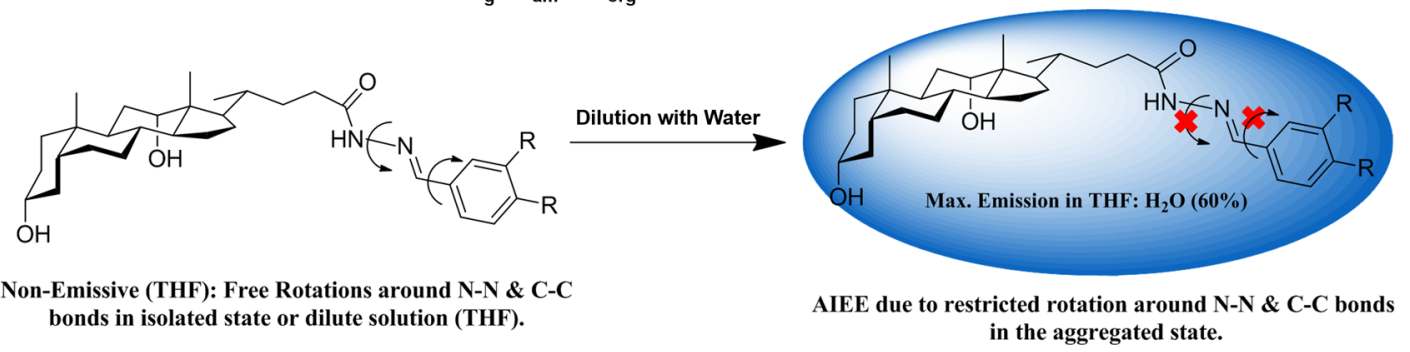

Figure 5. (a) PL spectra of $\mathrm{O}_{\mathrm{g}} \mathrm{TO}_{\mathrm{am}}-\mathrm{CD}_{\text {org }}$ in different fractions of the THF/water mixture. (b) Fluorescence images of the solutions under a UV lamp of $365 \mathrm{~nm}$. (c) Pictorial representation showing a plausible mechanism for PL emission in $\mathrm{O}_{\mathrm{g}} \mathrm{TO}_{\mathrm{am}}-\mathrm{CD}_{\text {org }}$ on dilution with a poor solvent (water) due to the "AIEE effect". $29,45-47$

$\mathrm{O}_{\mathrm{g}} \mathrm{TO}_{\mathrm{am}}-\mathrm{CD}_{\text {org }}$, two deconvoluted peaks at 401.05 and 399.29 $\mathrm{eV}$ representing $-\mathrm{C}-\mathrm{N}-\mathrm{N}$ (hydrazone moiety) and $\mathrm{C}-\mathrm{NH}$ (oleylamine), respectively, were obtained; however, in $\mathrm{O}_{\mathrm{g}} \mathrm{T}$ $\mathrm{CD}_{\text {org }}$, only one peak at $401.41 \mathrm{eV}(-\mathrm{C}-\mathrm{N}-\mathrm{N}$, the hydrazone moiety) could be obtained from its $\mathrm{N} 1 \mathrm{~s}$ band. In contrast, for the $\mathrm{O} 1 \mathrm{~s}$ band, two deconvoluted peaks were observed at 532.39 and $531.08 \mathrm{eV}$ in $\mathrm{O}_{\mathrm{g}} \mathrm{TO}_{\mathrm{am}}-\mathrm{CD}_{\text {org }}$ and 532.37 and 531.65 $\mathrm{eV}$ in $\mathrm{O}_{\mathrm{g}} \mathrm{T}-\mathrm{CD}_{\text {org }}$ assigned to $\mathrm{C}-\mathrm{OH} / \mathrm{C}-\mathrm{O}-\mathrm{C}$ and $\mathrm{C}=\mathrm{O}$, respectively. Thus, the above data including SEM, PL, and DLS provide a comprehensive demonstration on the successful synthesis of $\mathrm{CD}_{\text {org }}$ in comparison to others reports. ${ }^{22-24}$

AIEE Attribute of Organic CDs. Interestingly, $\mathrm{O}_{\mathrm{g}} \mathrm{TO}_{\mathrm{am}}{ }^{-}$ $\mathrm{CD}_{\text {org }}$ was found to be an AIEE-active candidate. To study this behavior, the solution of $\mathrm{O}_{\mathrm{g}} \mathrm{TO}_{\mathrm{am}}-\mathrm{CD}_{\text {org }}$ was prepared in THF/ water mixtures with different fractions $(0-90 \%(\mathrm{v} / \mathrm{v}))$ of water, a poor solvent for the organic CDs. The changes in the PL intensity were monitored at an excitation wavelength, $\lambda_{\text {ex }} \sim 380$ $\mathrm{nm}$ (maximum PL intensity), and are shown in Figure 5a. As evident, $50 \mu \mathrm{L}$ of the $\mathrm{O}_{\mathrm{g}} \mathrm{TO}_{\mathrm{am}}-\mathrm{CD}_{\text {org }}$ solution on dilution in $\mathrm{TO}_{\mathrm{am}}\left(\mathrm{THF} / \mathrm{O}_{\mathrm{am}}=9: 1\right.$, good solvent for $\left.\mathrm{CD}_{\mathrm{org}}\right)$ was almost nonemissive, showing a weak PL intensity with very low blue fluorescence under a UV lamp $(365 \mathrm{~nm})$. However, when water was added into it as a poor solvent, an instant enhancement in its PL intensity was observed. This $\mathrm{PL}$ intensity of $\mathrm{O}_{\mathrm{g}} \mathrm{TO}_{\mathrm{am}}{ }^{-}$ $\mathrm{CD}_{\text {org }}$ invigorated at $30 \%$ of water fraction in the THF/water mixture with a 2.5-fold enhancement, which reached its maximum value showing a 9.8 -fold increase at $60 \%$ fraction of water and also a bright blue fluorescence under a $365 \mathrm{~nm} \mathrm{UV}$ lamp (Figure $5 \mathrm{~b}$ ). Any addition of more $\%$ of water to the
$\mathrm{THF} /$ water mixture resulted in a decrease in the PL intensity well-reflected in their UV lamp fluorescence images.

In $\mathrm{O}_{\mathrm{g}} \mathrm{T}-\mathrm{CD}_{\mathrm{org}}$, the rotation of the $\mathrm{N}-\mathrm{N}$ single bond seemed quite feasible because of which very low PL emission was observed. $^{33}$ As $\mathrm{O}_{\mathrm{am}}$ was added, the viscosity of the solvent increased, thereby inducing restriction of such rotational motions of the $\mathrm{N}-\mathrm{N}$ single bond in $\mathrm{O}_{\mathrm{g}} \mathrm{TO}_{\mathrm{am}}-\mathrm{CD}_{\text {org }}$. These restrictions, in turn, restricted the nonradiative emissions and initiated the radiative processes. Hence, this has explained well the role of $\mathrm{O}_{\mathrm{am}}$ as a surface passivation agent in the $\mathrm{CD}_{\text {org }}$ system resulting in its enhanced PL intensity. In addition, the designation of $\mathrm{O}_{\mathrm{g}} \mathrm{TO}_{\mathrm{am}}-\mathrm{CD}_{\text {org }}$ as an AIEE system could be easily verified by the experiment performed in Figure 5. The dilution of $\mathrm{O}_{\mathrm{g}} \mathrm{TO}_{\mathrm{am}}-\mathrm{CD}_{\text {org }}$ in THF (a good solvent for $\mathrm{CD}_{\text {org }}$ ) lowered the viscosity of the medium and thus became almost nonemissive. ${ }^{29,45-47}$ On addition of water (a poor solvent for $\mathrm{CD}_{\text {org }}$ ) to the medium, the formation of $\mathrm{O}_{\mathrm{g}} \mathrm{TO}_{\mathrm{am}}-\mathrm{CD}_{\text {org }}$ aggregates commenced. With more fraction of water (30$70 \%(\mathrm{v} / \mathrm{v})), \mathrm{O}_{\mathrm{g}} \mathrm{TO}_{\mathrm{am}}-\mathrm{CD}_{\text {org }}$ clustered to form nanoaggregates (Figure 6) owing to its poor solubility; thereby, its PL intensity dramatically increased confirming the presence of an AIEE effect in $\mathrm{O}_{\mathrm{g}} \mathrm{TO}_{\mathrm{am}}-\mathrm{CD}_{\text {org }}$.

Thus, we can say here that, to the best of our knowledge, $\mathrm{O}_{\mathrm{g}} \mathrm{TO}_{\mathrm{am}}-\mathrm{CD}_{\text {org }}$ is the first reported bile acid-based CD system (in an organic or aqueous medium) to successfully show an AIEE effect. In addition, it can be noted that the organogelator was nonemissive in the solution state but became emissive on forming an organogel $\left(\mathrm{O}_{\mathrm{g}}\right)$ with DMSO. This could be due to restriction of energy-consuming motions on gelation owing to intermolecular $\mathrm{H}$-bonding and obvious physical constraints. ${ }^{29}$ 


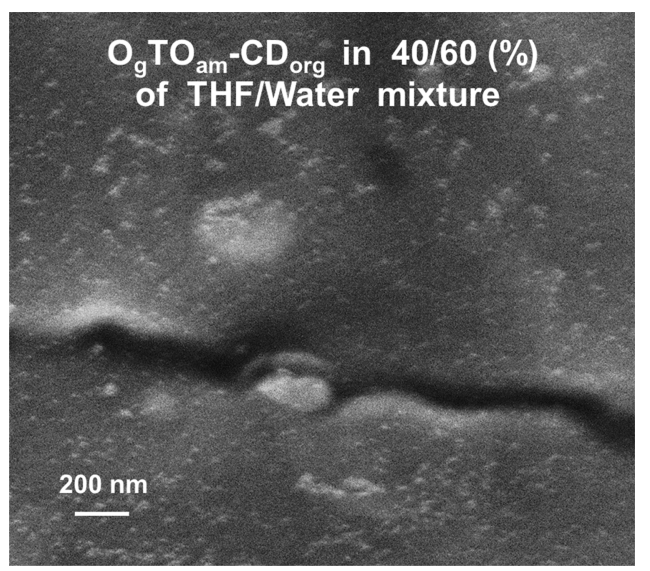

Figure 6. SEM image of $\mathrm{O}_{\mathrm{g}} \mathrm{TO}_{\mathrm{am}}-\mathrm{CD}_{\text {org }}$ showing the formation of nanoaggregates in a $40 / 60(\%) \mathrm{THF} /$ water mixture.

The Fourier transformed infrared (FTIR) spectrum of $\mathrm{O}_{g}$ (Figure 7) supported these facts, showing a broader peak around $3447 \mathrm{~cm}^{-1}$ and also a sharp and large peak at $1033 \mathrm{~cm}^{-1}$ of $-\mathrm{S}=\mathrm{O}$ rather than several peaks around $1033 \mathrm{~cm}^{-1}$ in the FTIR spectrum of the organogelator (Figure 7). Therefore, when gelation occurred, all of these interactions allowed a radiative emission pathway, rendering its fluorescence under a $365 \mathrm{~nm}$ UV lamp, as stated above.

Enzyme-Free Detection of Cholesterol by $\mathrm{O}_{\mathrm{g}} \mathrm{TO}_{\mathrm{am}}{ }^{-}$ $\mathrm{CD}_{\text {org }}$ through Fluorescence Turn-On: An AIEE Effect. The applicability of the AIEE attribute possessed by $\mathrm{O}_{\mathrm{g}} \mathrm{TO}_{\mathrm{am}}{ }^{-}$ $\mathrm{CD}_{\text {org }}$ was explored further to show its potential as an enzymefree sensing probe for cholesterol detection through a systematic study. At first, a $0.1 \mathrm{mM}$ solution of cholesterol (Chl) was prepared in THF for the analysis. Interestingly, on adding $100 \mu \mathrm{L}$ of $\mathrm{Chl}$ solution to $1 \mathrm{~mL}$ of $\mathrm{O}_{\mathrm{g}} \mathrm{TO}_{\mathrm{am}}-\mathrm{CD}_{\text {org }}$, an instant increase in its PL intensity was observed. This increase in the PL intensity got enhanced on gradual addition of more $0.1 \mathrm{mM}$ Chl solution. To determine the sensitivity of the study, $0.5 \mathrm{mM}, 1 \mu \mathrm{M}$, and $0.5 \mu \mathrm{M}$ solutions of Chl were prepared and added into the $\mathrm{O}_{\mathrm{g}} \mathrm{TO}_{\mathrm{am}}-\mathrm{CD}_{\text {org }}$ solution in a stepwise manner. $\mathrm{O}_{\mathrm{g}} \mathrm{TO}_{\mathrm{am}}-\mathrm{CD}_{\text {org }}$ showed a progressive increase in its PL intensity upon addition of $\mathrm{Chl}$ solutions of different concentrations. To quantify the net level of cholesterol responsible in triggering this turn-on in the $\mathrm{PL}$ intensity of $\mathrm{O}_{\mathrm{g}} \mathrm{TO}_{\mathrm{am}}-\mathrm{CD}_{\mathrm{org}}$, the concentration of cholesterol in the cuvette was calculated for every volume of cholesterol solution added to it. As depicted in
Figure $8 \mathrm{a}$, the minimum increase in the PL intensity was observed in the presence of $0.12 \mu \mathrm{M}$ cholesterol, below which no change in the PL intensity was evident. We studied this enhancement in the PL intensity up to an in-cuvette cholesterol concentration of $0.50 \mathrm{mM}$ showing a $\sim 2$-fold enhancement in the PL intensity of $\mathrm{O}_{\mathrm{g}} \mathrm{TO}_{\mathrm{am}}-\mathrm{CD}_{\text {org }}$ (Figure 8a).

Clearly, the as-prepared $\mathrm{O}_{\mathrm{g}} \mathrm{TO}_{\mathrm{am}}-\mathrm{CD}_{\text {org }}$ possesses analytical characteristics to detect different levels of cholesterol through an easy turn-on in its PL intensity with an important advantage, viz., the cholesterol sensor is devoid of the expensive cholesterol oxidase enzyme, making it superior in comparison to the already reported sensors for cholesterol. The relative PL intensity $\left(I / I_{0}\right)$ of $\mathrm{O}_{\mathrm{g}} \mathrm{TO}_{\mathrm{am}}-\mathrm{CD}_{\text {org }}$ at $427 \mathrm{~nm}$ versus the concentration of $\mathrm{Chl}$ is plotted in Figure $8 \mathrm{~b}$. Here, " $I$ " denotes the PL intensity of $\mathrm{O}_{\mathrm{g}} \mathrm{TO}_{\mathrm{am}}-\mathrm{CD}_{\text {org }}$ at $427 \mathrm{~nm}$ on adding $500 \mu \mathrm{L}$ of Chl solution of different concentrations, and " $I_{0}$ " denotes the initial PL of $\mathrm{O}_{\mathrm{g}} \mathrm{TO}_{\mathrm{am}}-\mathrm{CD}_{\text {org }}$ at $427 \mathrm{~nm}$ in the absence of any $\mathrm{Chl}$ solution. Interestingly, the $\mathrm{PL}$ intensity of $\mathrm{O}_{\mathrm{g}} \mathrm{TO}_{\mathrm{am}}-\mathrm{CD}_{\text {org }}$ increased linearly with the concentration of $\mathrm{Chl}$ from $0.05 \mu \mathrm{M}$ to $0.5 \mathrm{mM}$ with $R^{2}=0.97153$, a value close to 1 validating a good linear fitting. Accordingly, the LOD and LOQ assessed from the calibration plot showed a value of 1.09 and $3.64 \mu \mathrm{M}$, respectively. Therefore, it can be said that $\mathrm{O}_{\mathrm{g}} \mathrm{TO}_{\mathrm{am}}-\mathrm{CD}_{\text {org }}$ has the potential to serve as a successful fluorescence turn-on sensor for the enzyme-free detection of cholesterol.

The interaction of $\mathrm{Chl}$ with $\mathrm{O}_{\mathrm{g}} \mathrm{TO}_{\mathrm{am}}-\mathrm{CD}_{\text {org }}$ could be explained by the formation of a $\mathrm{H}$-bond between the $\mathrm{Chl}$ moiety and the functional groups present in $\mathrm{O}_{\mathrm{g}} \mathrm{TO}_{\mathrm{am}}-\mathrm{CD}_{\text {org }}$. The $-\mathrm{OH}$ group in $\mathrm{Chl}$ and two $-\mathrm{OH}$ groups, a $\mathrm{C}=\mathrm{O}$ group, and $-\mathrm{NH}-\mathrm{N}=$ groups in $\mathrm{O}_{\mathrm{g}} \mathrm{TO}_{\mathrm{am}}-\mathrm{CD}_{\mathrm{org}}$ were readily available for intermolecular H-bonding. The FTIR study (Figure 9a) provided the proof of the interaction between these groups. In $\mathrm{O}_{\mathrm{g}} \mathrm{T}-\mathrm{CD}_{\mathrm{org}}$, the peaks at 2926 and $2854 \mathrm{~cm}^{-1}\left(\nu_{\mathrm{C}-\mathrm{H}}\right)$ were intense, signifying the presence of more number of aliphatic carbon chains on the surface of $\mathrm{O}_{\mathrm{g}} \mathrm{T}-\mathrm{CD}_{\mathrm{org}}$, which in turn also justified its solubility in an organic solvent. ${ }^{17}$ In addition, the peaks at $1742 \mathrm{~cm}^{-1}\left(\nu_{\mathrm{C}=\mathrm{O}}\right)$ and $1667 \mathrm{~cm}^{-1}\left(\nu_{\mathrm{C}=\mathrm{N}}\right)$ confirmed that the preparative reflux conditions did not jeopardize the molecular integrity of the organogelator to form $\mathrm{CD}_{\text {org }}$. As FTIR spectroscopy is an interpretation of molecular motions, the drastic decrease in the intensity of these peaks in $\mathrm{O}_{\mathrm{g}} \mathrm{TO}_{\mathrm{am}}{ }^{-}$ $\mathrm{CD}_{\text {org }}$ gave an indication of restrictions in molecular motions of these bonds on the addition of $\mathrm{O}_{\mathrm{am}}$, causing the AIEE effect. The interaction of $\mathrm{O}_{\mathrm{g}} \mathrm{TO}_{\mathrm{am}}-\mathrm{CD}_{\text {org }}$ with $\mathrm{Chl}$ further decreased the peak intensities, confirming a greater restriction of
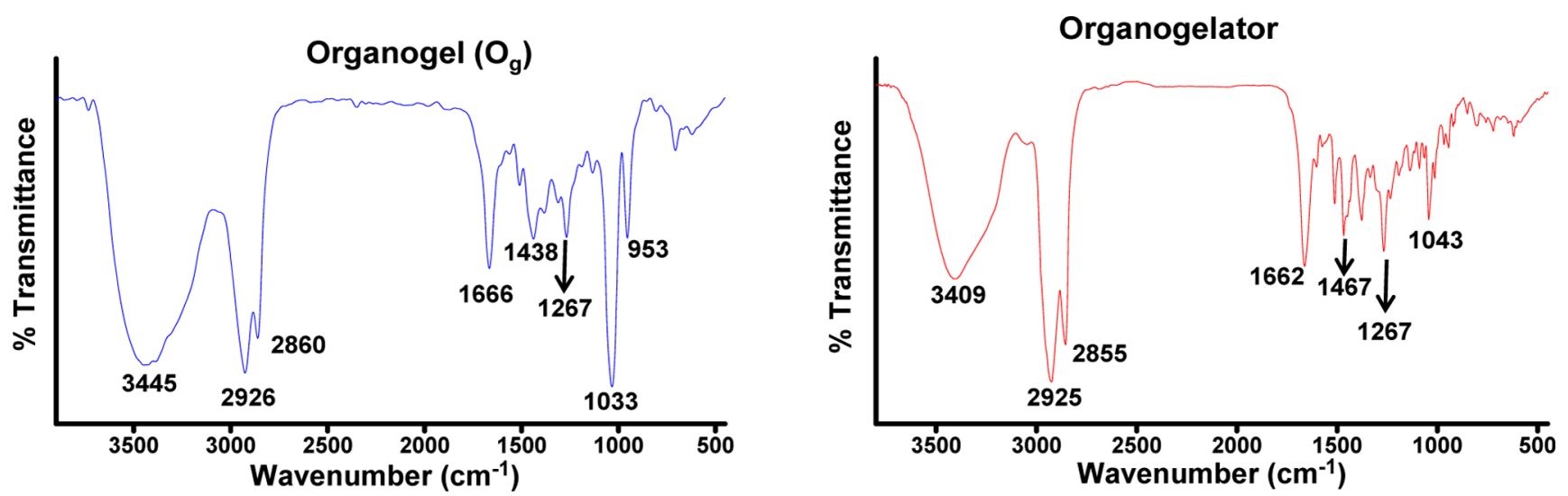

Figure 7. FTIR spectra of the organogel $\left(\mathrm{O}_{\mathrm{g}}\right)$ and organogelator (deoxycholic acid hydrazone compound). 

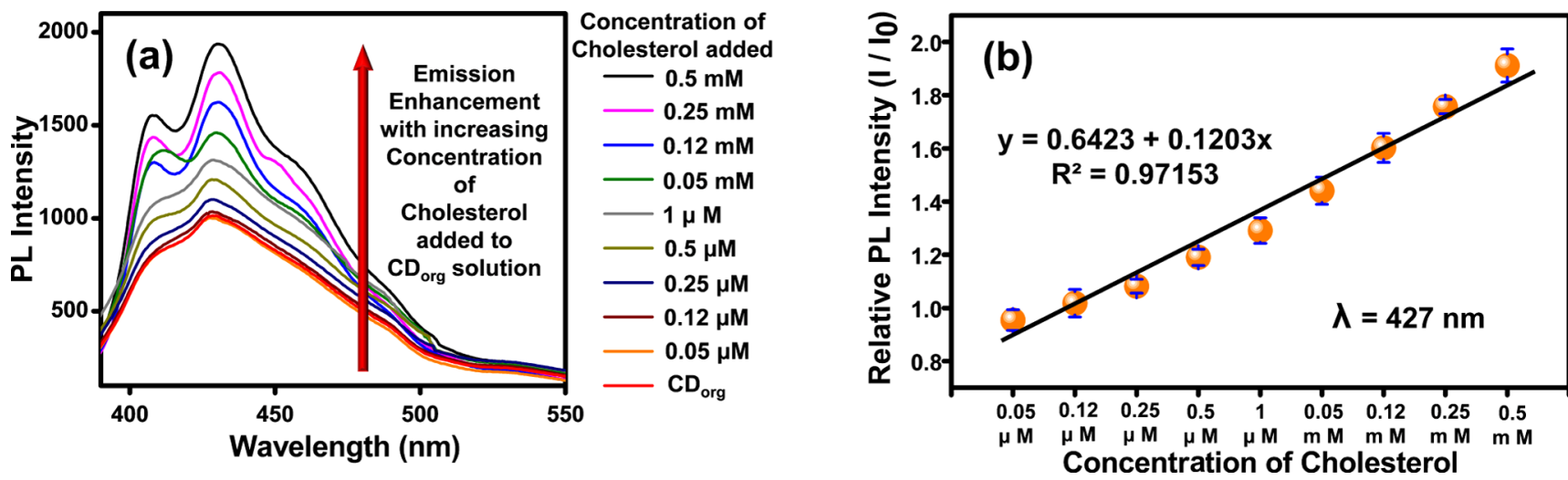

Figure 8. (a) PL spectra showing turn-on fluorescence sensing in the presence of cholesterol (Chl) concentrations of $0.05 \mu \mathrm{M}$ to $0.5 \mathrm{mM}$. (b) Linearly fitted calibration plot of relative PL intensity $\left(I / I_{0}\right.$ at $427 \mathrm{~nm}$ ) vs the concentration of cholesterol (Chl) from $0.05 \mu \mathrm{M}$ to $0.5 \mathrm{mM}$ (inset: linear equation and regression $\left(R^{2}\right)$ value estimated from the plot).

\section{(a) FTIR Analysis}

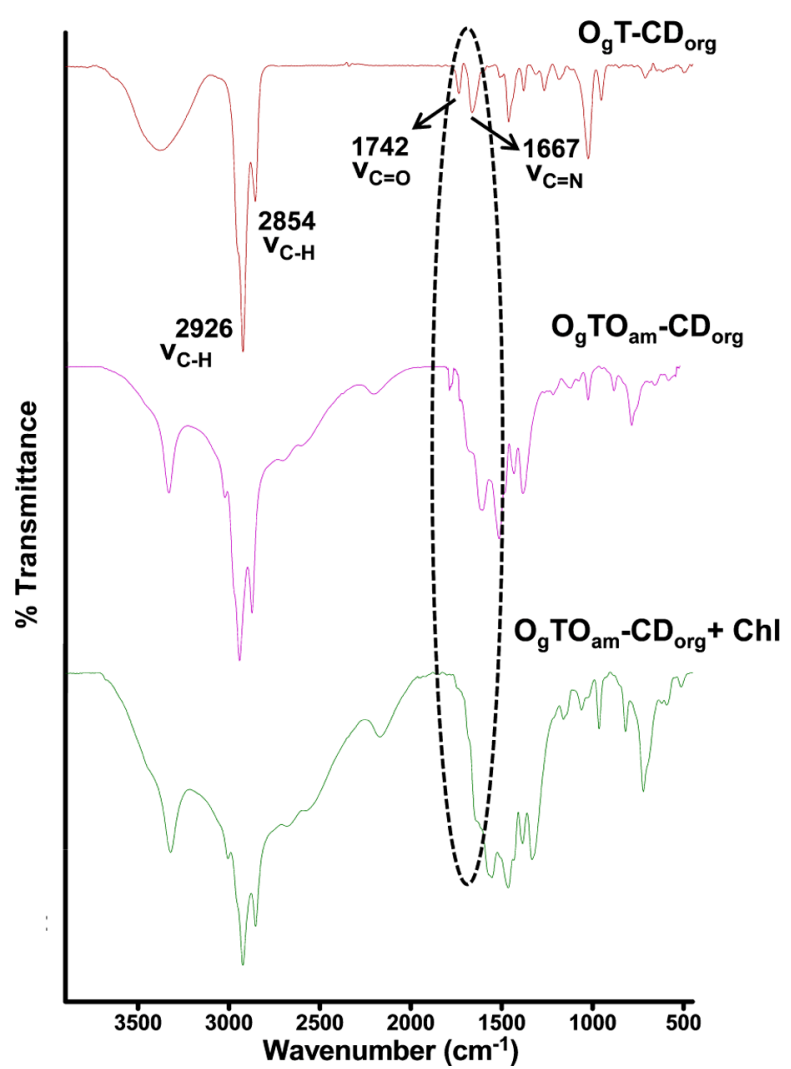

(b) SEM Image

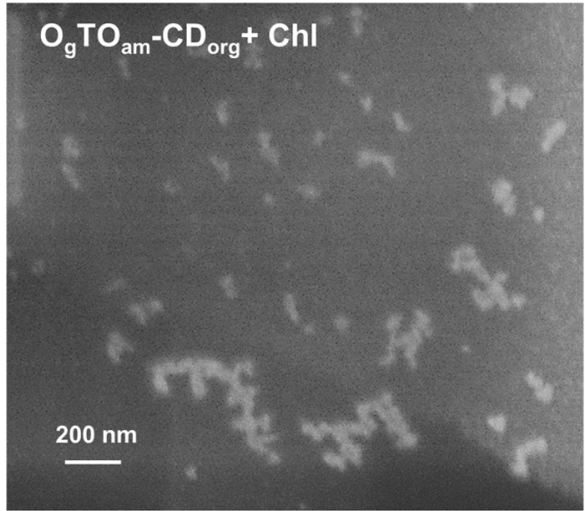

(c) Interference Study

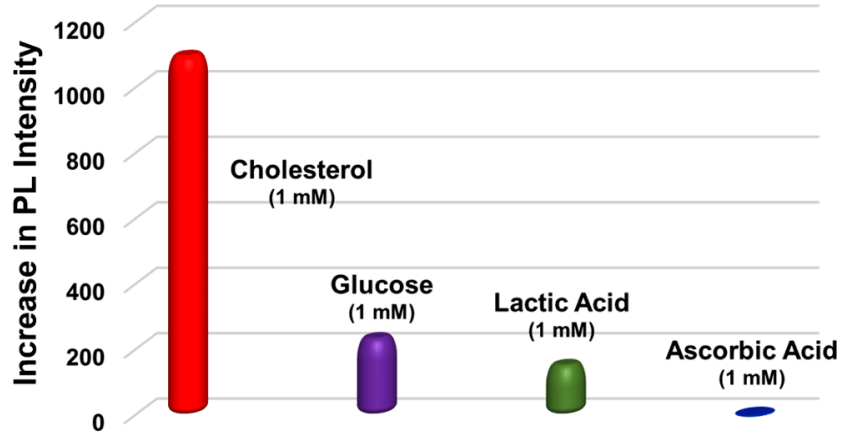

Figure 9. (a) FTIR spectra of $\mathrm{O}_{\mathrm{g}} \mathrm{T}-\mathrm{CD}_{\text {org }} \mathrm{O}_{\mathrm{g}} \mathrm{TO}_{\mathrm{am}}-\mathrm{CD}_{\text {org }}$, and $\mathrm{O}_{\mathrm{g}} \mathrm{TO}_{\mathrm{am}}-\mathrm{CD}_{\text {org }}+\mathrm{Chl}$. (b) SEM image of $\mathrm{O}_{\mathrm{g}} \mathrm{TO}_{\mathrm{am}}-\mathrm{CD}_{\text {org }}+\mathrm{Chl}_{\text {showing the }}$ formation on nanoaggregates. (c) Interference study of $\mathrm{O}_{\mathrm{g}} \mathrm{TO}_{\mathrm{am}}-\mathrm{CD}_{\mathrm{org}}$ by other biomolecules (glucose, Glu; lactic acid, LaA; ascorbic acid, AsA).

molecular motions in the presence of $\mathrm{Chl}$. As these restrictions showed an enhancement in PL emission, it can be said that Chl molecules formed coaggregates with $\mathrm{O}_{\mathrm{g}} \mathrm{TO}_{\mathrm{am}}-\mathrm{CD}_{\text {org }}$ on occurrence of such H-bonding, ${ }^{29}$ depicted clearly in its SEM image (Figure 9b). Consequently, the nonradiative emission of $\mathrm{O}_{\mathrm{g}} \mathrm{TO}_{\mathrm{am}}-\mathrm{CD}_{\text {org }}$ got suppressed by the radiative decay pathway showing the enhanced PL emission, as well explained in the Introduction and Results and Discussion sections.

For any sensing system, the interference by other molecules could be a major drawback in the study. Therefore, to check the selectivity of $\mathrm{O}_{\mathrm{g}} \mathrm{TO}_{\mathrm{am}}-\mathrm{CD}_{\text {org }}$ for cholesterol, we conducted an interference analysis with ascorbic acid (AsA), glucose (Glu), and lactic acid (LaA), taking reference from the previous reports. For the study, AsA, Glu, and LaA were analyzed by $\mathrm{O}_{\mathrm{g}} \mathrm{TO}_{\mathrm{am}}-\mathrm{CD}_{\text {org }}$ in a similar manner as that done in Chl. Interestingly, $\mathrm{O}_{\mathrm{g}} \mathrm{TO}_{\mathrm{am}}-\mathrm{CD}_{\text {org }}$ did not show any significant change in its PL intensity in the presence of $0.1 \mathrm{mM}$ solutions of AsA, Glu, and LaA, as evident from Figure 9c. Clearly, this suggests that $\mathrm{O}_{\mathrm{g}} \mathrm{TO}_{\mathrm{am}}-\mathrm{CD}_{\text {org }}$ has good control in its selectivity toward Chl, exclusively.

Cholesterol Sensing in the Human Blood Serum. The feasibility of $\mathrm{O}_{\mathrm{g}} \mathrm{TO}_{\mathrm{am}}-\mathrm{CD}_{\text {org }}$ to successfully serve as a 


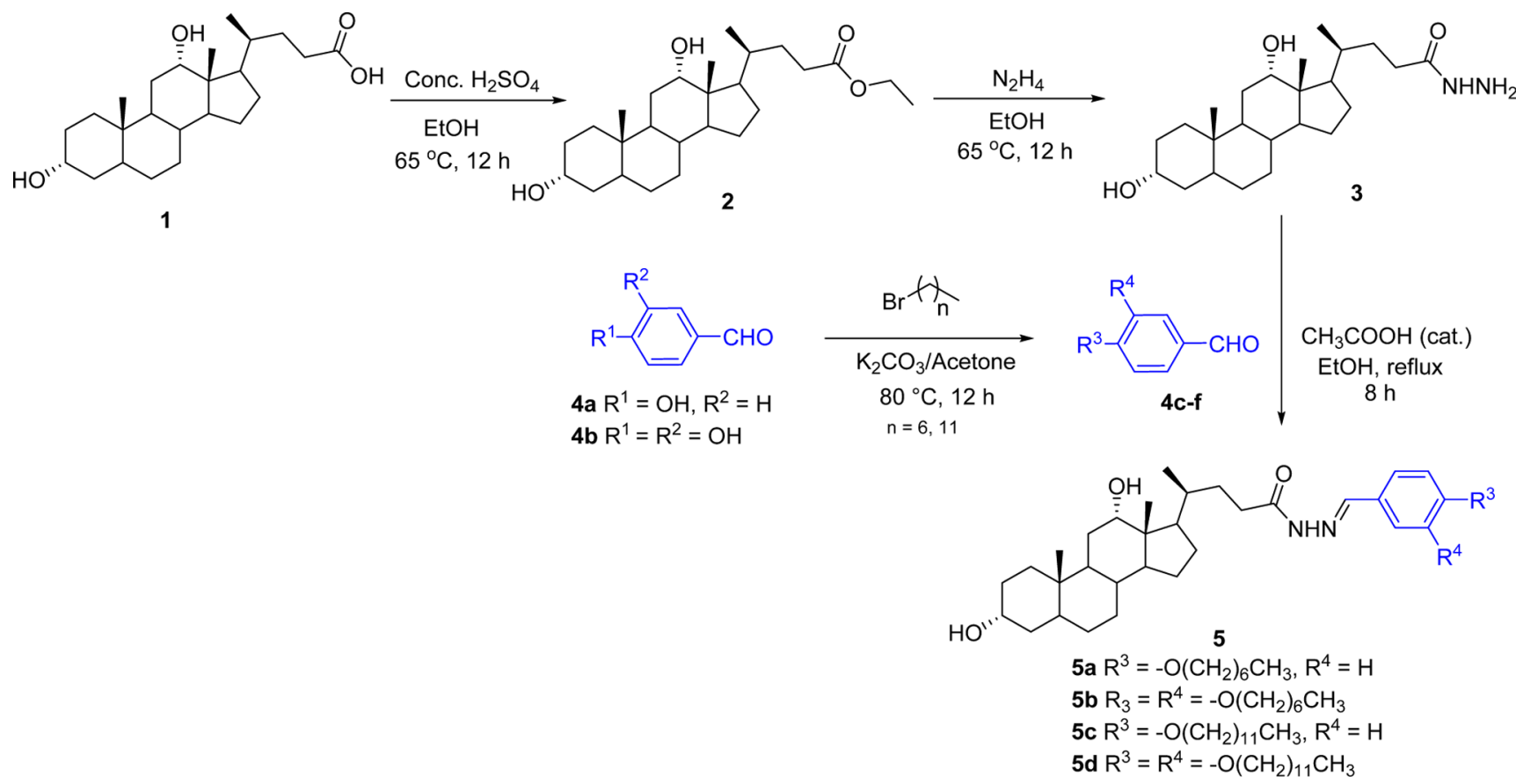

Figure 10. Synthesis of the organogelator deoxycholic acid hydrazone-based compound, $5 \mathrm{~d}\left((4 R)-N^{\prime}-((E)-3,4-b i s(\right.$ dodecyloxy)benzylidene)-4$((3 R, 10 S, 12 S, 13 R)$-3,12-dihydroxy-10,13-dimethylhexadecahydro-1H-cyclopenta-[a]-phenanthren-17-yl)pentane-hydrazide)

cholesterol sensing probe in the human blood serum was also tested to provide a proof-of-concept for its practical applicability. The sensing analysis was performed on two human blood serum samples collected from Pratiksha Hospital, Assam, India. An instant enhancement in the PL intensity of $\mathrm{O}_{\mathrm{g}} \mathrm{TO}_{\mathrm{am}}-\mathrm{CD}_{\text {org }}$ was witnessed on the addition of the blood serum to it (Figure S3a). A calibration curve (Figure S3b) plotted to calculate the concentration level of $\mathrm{Chl}$ gave the values of $239 \mathrm{mg} / \mathrm{dL}$ and $183 \mathrm{mg} / \mathrm{dL}$ for the level of $\mathrm{Chl}$ present in the samples, whose actual values are 201 and 193 $\mathrm{mg} / \mathrm{dL}$, respectively (as reported by the hospital). In conclusion, the results obtained by our $\mathrm{O}_{\mathrm{g}} \mathrm{TO}_{\mathrm{am}}-\mathrm{CD}_{\text {org }}$ system gave quite satisfactory validation regarding its potential to be used as a cheap cholesterol sensor.

Moreover, this enzyme-free fluorescence turn-on sensor of cholesterol features several superiorities in comparison to its contemporary sensors. First, the sensing probe and all the associated reagents are very simple and cost-effective. Second, our sensing system does not involve any enzyme for the detection of $\mathrm{Chl}$, which further lowers the cost and limitations involved in the study to a larger extent. Third, the sensitivity is found to be very good, and the interference by other biomolecules is also negligible, making it a selective and sensitive cholesterol sensor. Convincingly, all the above stated advantages of this sensing system are the worthy rewards of the AIEE attribute of $\mathrm{O}_{\mathrm{g}} \mathrm{TO}_{\mathrm{am}}-\mathrm{CD}_{\text {org }}$.

\section{CONCLUSIONS}

In this study, fluorescent organic $\mathrm{CDs}\left(\mathrm{O}_{\mathrm{g}} \mathrm{TO}_{\mathrm{am}}-\mathrm{CD}_{\text {org }}\right)$ possessing the amazing AIEE attribute were synthesized from a novel bile acid-based organogel in a quick one-pot strategy. The organogel $\left(\mathrm{O}_{\mathrm{g}}\right)$ was prepared from a novel deoxycholic acid hydrazone-based compound $\left((4 R)-N^{\prime}-((E)-3,4\right.$-bis(dodecyloxy)benzylidene)-4-((3R,10S,12S,13R)-3,12-dihydroxy-10,13-dimethylhexadecahydro- $1 H$-cyclopenta-[a]-phenanthren-17-yl)pentane-hydrazide), exclusively synthesized in our laboratory as a DMSO-gelator. The $\mathrm{O}_{\mathrm{g}} \mathrm{TO}_{\mathrm{am}}-\mathrm{CD}_{\text {org }}$ was prepared by refluxing $\mathrm{O}_{\mathrm{g}}$ in a 9:1 ratio solution of THF/ oleylamine $\left(\mathrm{TO}_{\mathrm{am}}\right)$ at $100{ }^{\circ} \mathrm{C}$ and $400 \mathrm{rpm}$ under $\mathrm{N}_{2}$ flow, and its PL emission was studied at $\lambda_{\mathrm{ex}} \sim 380,400,420,440,460$, 480 , and $500 \mathrm{~nm}$. The organic $\mathrm{CD}, \mathrm{O}_{\mathrm{g}} \mathrm{TO}_{\mathrm{am}}-\mathrm{CD}_{\mathrm{org}}$, was found to possess the AIEE effect in different THF/water (v/v) mixtures, which was investigated through PL and SEM studies. The maximum AIEE effect was evident in the 40/60(\%) THF/ water mixture, which showed a 9.8 -fold increase in the PL intensity and also a bright blue fluorescence under a $365 \mathrm{~nm}$ UV lamp. This could be attributed to the formation of nanoaggregates of $\mathrm{O}_{\mathrm{g}} \mathrm{TO}_{\mathrm{am}}-\mathrm{CD}_{\text {org }}$ at the $40 / 60(\%) \mathrm{THF} /$ water mixture causing restrictions in molecular motions. In doing so, the nonradiative pathway gets limited and the radiative pathway for the decay of excitons gets initiated, thus offering an enhancement in the PL emission. The applicability of this AIEE attribute was explored to show its potential as an enzyme-free fluorescence turn-on sensor for cholesterol (Chl) with a LOD and LOQ of 1.09 and $3.64 \mu \mathrm{M}$, respectively. The enhancement in the PL intensity of $\mathrm{O}_{\mathrm{g}} \mathrm{TO}_{\mathrm{am}}-\mathrm{CD}_{\text {org }}$ in the presence of $\mathrm{Chl}$ molecules could also be credited to the formation of nanoaggregates and consequential radiative decay pathways for excitons. The fluorescence turn-on $\mathrm{Chl}$ detection by $\mathrm{O}_{\mathrm{g}} \mathrm{TO}_{\mathrm{am}}-\mathrm{CD}_{\text {org }}$ also showed its feasibility in the human blood serum with a minimum error. Therefore, this AIEE-based organic $\mathrm{CD}$ system is a unique fluorescence material in an organic medium with the most desirable qualities and an important application of cholesterol sensing in the human blood serum.

\section{EXPERIMENTAL SECTION}

Materials and Equipment. Dimethyl sulfoxide (DMSO) (Merck), THF (Merck), An (Merck), Hx (Merck), Tu (Merck), Ech (Merck), oleylamine $\left(\mathrm{O}_{\mathrm{am}}\right)$, cholesterol (Chl) (Merck), AsA (Merck), Glu (Sigma-Aldrich), and LaA (Merck) were used as received. All other materials used were of 

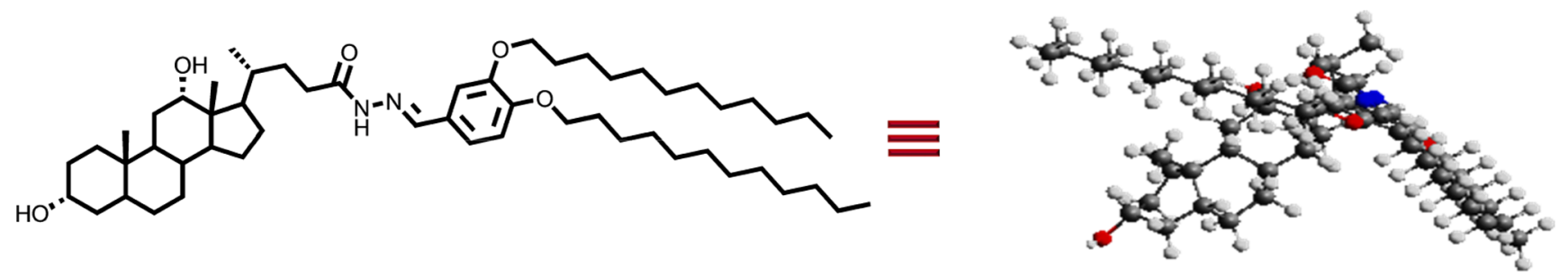

Figure 11. Molecular structure of deoxycholic acid-based hydrazone (5d) used as the organogelator.

Scheme 2. Synthesis of an Organic CD $\left(\mathrm{O}_{\mathrm{g}} \mathrm{TO}_{\mathrm{am}}-\mathrm{CD}_{\mathrm{org}}\right)$ from an Organogel $\left(\mathrm{O}_{\mathrm{g}}\right)$ in a 9:1 $\mathrm{THF} / \mathrm{O}_{\mathrm{am}}\left(\mathrm{TO}_{\mathrm{am}}\right)$ Solution

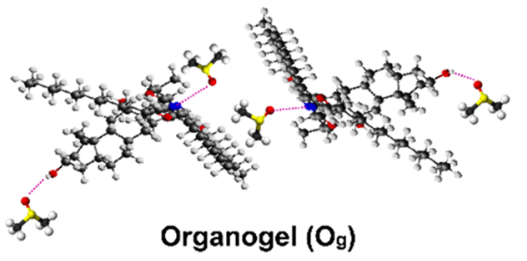

Reflux at $100^{\circ} \mathrm{C} \& 400 \mathrm{rpm}$ under $\mathrm{N}_{2}$ atmosphere
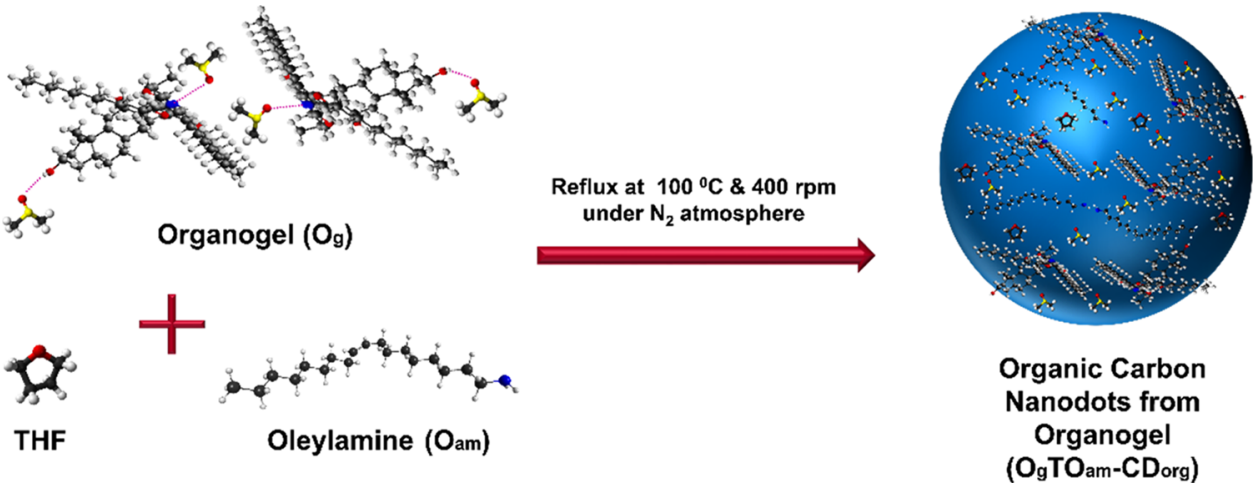

analytical reagent grade from commercial sources. The $\mathrm{CD}_{\text {org }}$ solution was characterized by PL spectroscopy (JASCO spectrofluorometer-FP 8300) to study its fluorescence behavior. The spectra were obtained at the excitation wavelengths $\left(\lambda_{\mathrm{ex}}\right)$ of $380,400,420,440,460,480$, and $500 \mathrm{~nm}$. The surface morphology was investigated using an SEM from Carl Zeiss (Sigma VP). For the SEM analysis, the $\mathrm{CD}_{\text {org }}$ solution was drop-casted on a silicon wafer $(\sim 1 \mathrm{~cm} \times 1 \mathrm{~cm})$ and dried in air, followed by $\mathrm{Au} / \mathrm{Pd}$ alloy coating in vacuum, and was used for imaging. The XPS elemental analysis was performed using a commercial Omicron EA 125 spectrometer having a sevenchannel detection system. The particle size distribution analyses were performed with a Malvern Zetasizer NanoZS 90. The FTIR spectroscopic measurements of the samples were recorded in a Bruker FTIR spectrophotometer. The samples were prepared in the form of potassium bromide $(\mathrm{KBr})$ pellets by drop-casting the $\mathrm{CD}_{\text {org }}$ solution onto prepared $\mathrm{KBr}$ pellets of IR spectroscopic grade and then drying at $60{ }^{\circ} \mathrm{C}$.

General Procedure for the Synthesis of Deoxycholic Acid-Based Hydrazones $(5 a-d)$ as a Precursor for Organogel. To a hot solution of $3(1 \mathrm{mmol})$ and 6 (1 $\mathrm{mmol})$ in ethanol $(20 \mathrm{~mL})$, a catalytic amount of glacial acetic acid was added, and the reaction mixture was refluxed for $8 \mathrm{~h}$. The completion of the reaction was monitored by thin-layer chromatography. After the completion of the reaction, the reaction mixture was cooled to room temperature, and the formed precipitate was filtered under reduced pressure to yield the crude product, which was recrystallized using An to give the pure product (Figure 10). Among $5 \mathrm{a}-\mathrm{d}, 5 \mathrm{~d}$ was used for the preparation of the organogel as a precursor of $\mathrm{CD}_{\text {org }}$ as it showed the best gelation property with stability at room temperature (details provided in Supporting Information (SI)).

Synthesis of Organogel $\left(\mathbf{O}_{\mathrm{g}}\right)$. The organogel $(8 \%)$ was prepared in DMSO using deoxycholic acid hydrazone-based compound $5 \mathrm{~d}$ as the organogelator (Figure 11). Briefly, $0.08 \mathrm{~g}$ of the organogelator was dispersed in $1 \mathrm{~mL}$ of DMSO, followed by heating at $100{ }^{\circ} \mathrm{C}$ for $20 \mathrm{~min}$. The dispersion was allowed to cool down to room temperature and was kept in a refrigerator for $12 \mathrm{~h}$ resulting in the solidification of the dispersion, which was then kept at room temperature. The hard solid gradually melted down and resulted in the formation of a gel-like structure after 5-6 h.

Synthesis of Organic CD $\left(C D_{\text {org }}\right)$ from Organogel $\left(O_{g}\right)$ in THF $\left(\mathrm{O}_{\mathrm{g}} \mathrm{T}-\mathrm{CD}_{\text {org }}\right)$. Approximately, $0.1 \mathrm{~g}$ of $\mathrm{O}_{\mathrm{g}}$ was dispersed in $10 \mathrm{~mL}$ of THF. The solution was then allowed to reflux at $100{ }^{\circ} \mathrm{C}$ with $400 \mathrm{rpm}$ magnetic stirring under $\mathrm{N}_{2}$ flow. After $1 \mathrm{~h}$ of reflux, the $\mathrm{CD}_{\text {org }}$ solution was cooled down to room temperature and stored as $\mathrm{O}_{\mathrm{g}} \mathrm{T}-\mathrm{CD}_{\text {org }}$. Likewise, four other solvents, $\mathrm{Tu}, \mathrm{Hx}, \mathrm{An}$, and $\mathrm{Ech}$, were also investigated for the synthesis of $\mathrm{CD}_{\text {org }}$ from $\mathrm{O}_{\mathrm{g}}$.

Synthesis of Organic CD $\left(C D_{\text {org }}\right)$ from Organogel $\left(O_{g}\right)$ in THF/Oleylamine $\left(\mathrm{O}_{\mathrm{g}} \mathrm{TO}_{\mathrm{am}}-\mathrm{CD}_{\mathrm{org}}\right)$. Next, we studied the potential role of oleylamine $\left(\mathrm{O}_{\mathrm{am}}\right)$ as a surface passivating agent for the synthesis of $\mathrm{CD}_{\text {org }}$. Initially, a 9:1 ratio solution of THF/ oleylamine $\left(\mathrm{TO}_{\mathrm{am}}\right)$ was prepared, into which $0.1 \mathrm{~g}$ of $\mathrm{O}_{\mathrm{g}}$ was dispersed and then refluxed following the same procedure as that followed in $\mathrm{O}_{\mathrm{g}} \mathrm{T}-\mathrm{CD}_{\text {org }}$. After a $1 \mathrm{~h}$ reflux, the solution was stored as $\mathrm{O}_{\mathrm{g}} \mathrm{TO}_{\mathrm{am}}-\mathrm{CD}_{\text {org }}$ (Scheme 2).

AIEE Assay of $\mathrm{O}_{\mathrm{g}} \mathrm{TO}_{\mathrm{am}}-\mathrm{CD}_{\text {org }}$. The solutions of $\mathrm{O}_{\mathrm{g}} \mathrm{TO}_{\mathrm{am}}{ }^{-}$ $\mathrm{CD}_{\text {org }}$ in different mixtures $(\mathrm{v} / \mathrm{v})$ of $\mathrm{THF} /$ water were prepared by adding $50 \mu \mathrm{L}$ of $\mathrm{O}_{\mathrm{g}} \mathrm{TO}_{\mathrm{am}}-\mathrm{CD}_{\text {org }}$ into $1 \mathrm{~mL}$ solution of the mixture with different fractions of water. For preparing the THF/water mixture, a 9:1 ratio solution of THF/oleylamine $\left(\mathrm{TO}_{\mathrm{am}}\right)$ was used as the solvent, as $\mathrm{O}_{\mathrm{g}} \mathrm{TO}_{\mathrm{am}}-\mathrm{CD}_{\text {org }}$ was prepared in this solvent ratio. Then, a total of $10 \mathrm{THF} /$ water mixtures (v/v), viz., 90/10, 80/20, 70/30, 60/40, 50/50, 40/60, $30 / 70,20 / 80,10 / 90$, and $0 / 100$, were prepared containing 10 , $20,30,40,50,60,70,80,90$, and $100 \%$ fractions of water, respectively. The PL measurements of the resultant solutions were taken at the excitation wavelength $\left(\lambda_{\mathrm{ex}}\right)$ of $380 \mathrm{~nm}$. The respective fluorescence images of the solutions under a UV lamp of $365 \mathrm{~nm}$ were also obtained simultaneously.

Investigation of $\mathrm{O}_{\mathrm{g}} \mathrm{TO}_{\mathrm{am}}-\mathrm{CD}_{\mathrm{org}}$ as a Fluorescence Sensing Probe for Cholesterol. The potential of $\mathrm{CD}_{\text {org }}$ as 
a fluorescence sensor for enzyme-free detection of cholesterol was investigated. A $0.1 \mathrm{mM}$ solution of cholesterol (Chl) in THF was prepared. For the sensing analysis, to a $1 \mathrm{~mL}$ solution of $\mathrm{O}_{\mathrm{g}} \mathrm{TO}_{\mathrm{am}}-\mathrm{CD}_{\text {org }}, 1000 \mu \mathrm{L}$ of $\mathrm{Chl}$ solution was added stepwise, with a $100 \mu \mathrm{L}$ volume in each step, followed by obtaining a PL spectrum subsequently. Similarly, the sensitivity of $\mathrm{O}_{\mathrm{g}} \mathrm{TO}_{\mathrm{am}}{ }^{-}$ $\mathrm{CD}_{\text {org }}$ toward the detection of cholesterol was studied with concentrations of $0.5 \mathrm{mM}, 1 \mu \mathrm{M}$, and $0.5 \mu \mathrm{M}$ of Chl in THF.

Interference Study. The interference of other analytes is a major limitation of any sensing material. To investigate such interference in our system, AsA, Glu, and LaA were considered as the interfering analytes. A $1 \mathrm{mM}$ solution of each of the analytes was prepared and tested as per the procedure followed in the detection of Chl.

Enzyme-Free Cholesterol Detection in the Human Blood Serum. The applicability of $\mathrm{O}_{\mathrm{g}} \mathrm{TO}_{\mathrm{am}}-\mathrm{CD}_{\text {org }}$ for detecting the level of cholesterol present in the human blood serum in the absence of any enzyme was examined. Two human blood serum samples with known levels of Chl were collected from Pratiksha Hospital, Guwahati, Assam, with the consent of the hospital authority. The blood serum was first dispersed in THF, followed by vigorous stirring for $5 \mathrm{~min}$ and addition into the $\mathrm{O}_{\mathrm{g}} \mathrm{TO}_{\mathrm{am}}-\mathrm{CD}_{\text {org }}$ solution whose $\mathrm{PL}$ spectrum was recorded. The level of $\mathrm{Chl}$ was then calculated from the calibration curve obtained from the standard solution of $\mathrm{Chl}$ in THF at different concentrations.

\section{ASSOCIATED CONTENT}

\section{S Supporting Information}

The Supporting Information is available free of charge on the ACS Publications website at DOI: 10.1021/acsomega.7b00643.

$\mathrm{PL}$ spectra of $\mathrm{O}_{\mathrm{g}} \mathrm{Tu}-\mathrm{CD}_{\text {org }}, \mathrm{O}_{\mathrm{g}} \mathrm{Hx}-\mathrm{CD}_{\text {org }}, \mathrm{O}_{\mathrm{g}} \mathrm{An}-\mathrm{CD}_{\text {org }}$, and $\mathrm{O}_{\mathrm{g}} \mathrm{Ec}-\mathrm{CD}_{\mathrm{org}}$ prepared from $\mathrm{O}_{\mathrm{g}}$; FTIR spectra of the organogel $\left(\mathrm{O}_{\mathrm{g}}\right)$ and organogelator (deoxycholic acid hydrazone compound); PL spectra showing turn-on fluorescence sensing of cholesterol in the presence of two different samples of the human blood serum by $\mathrm{O}_{\mathrm{g}} \mathrm{TO}_{\mathrm{am}}{ }^{-}$ $\mathrm{CD}_{\text {org; }}$ linearly fitted calibration plot of relative $\mathrm{PL}$ intensity $\left(I / I_{0}\right.$ at $\left.427 \mathrm{~nm}\right)$ versus the concentration of Chl from 1 to $6 \mathrm{mM}$; detailed synthesis of deoxycholic acid hydrazone-based compounds as organogelators; ${ }^{1} \mathrm{H}$ and ${ }^{13} \mathrm{C}$ NMR spectra of $5 \mathrm{a}-\mathrm{d}$; spectroscopic data of $5 \mathrm{a}-\mathrm{d}$; study of gelation behavior of organogelators (PDF)

\section{AUTHOR INFORMATION}

\section{Corresponding Author}

*E-mail: devasish@iasst.gov.in. Tel:+91 361 2912073. Fax: +91 3612279909.

\section{ORCID $\odot$}

Devasish Chowdhury: 0000-0003-4829-6210

Rajeev Sakhuja: 0000-0002-9284-9137

\section{Author Contributions}

${ }^{\S}$ N.G. and D.S.A. have contributed equally to this work.

\section{Author Contributions}

The manuscript was written through contributions of all authors.

\section{Notes}

The authors declare no competing financial interest.

\section{ACKNOWLEDGMENTS}

The authors would like to thank the Science and Engineering Research Board (SERB), New Delhi, for project grant SB/S1/ PC-69/2012 and Department of Science \& Technology (DST), New Delhi, for providing research grant (SB/FT/CS-033/ 2012). D.C. also thanks BRNS, Mumbai, for a research grant (34/14/20/2014-BRNS). We also thank IASST, Guwahati, and BITS Pilani for providing an additional research grant for the work. N.G. would like to thank CSIR, New Delhi, and D.S.A. would like to thank DST, New Delhi, for providing fellowships. The authors also thank Dr. Madhurjyo Bikash Gogoi, Gynecologist \& Obstetrics and the staff members of Pratiksha Hospital, Guwahati, Assam, India, for providing human blood serum samples.

\section{REFERENCES}

(1) Sekretaryova, A. N.; Beni, V.; Eriksson, M.; Karyakin, A. A.; Turner, A. P. F.; Vagin, M. Y. Cholesterol Self-Powered Biosensor. Anal. Chem. 2014, 86, 9540-9547.

(2) Li, G.; Liao, J. M.; Hu, G. Q.; Ma, N. Z.; Wu, P. J. Study of Carbon Nanotube Modified Biosensor for Monitoring Total Cholesterol in Blood. Biosens. Bioelectron. 2005, 20, 2140-2144.

(3) Tan, X.; Lia, M.; Cai, P.; Luo, L.; Zou, X. An Amperometric Cholesterol Biosensor Based on Multiwalled Carbon Nanotubes and Organically Modified Sol-Gel/Chitosan Hybrid Composite Film. Anal. Biochem. 2005, 337, 111-120.

(4) Bongiovanni, C.; Ferri, T.; Poscia, A.; Varalli, M.; Santucci, R.; Desideri, A. An Electrochemical Multienzymatic Biosensor for Determination of Cholesterol. Bioelectrochemistry 2001, 54, 17-22.

(5) Néabo, J. R.; Vigier-Carrière, C.; Rondeau-Gagné, S.; Morin, J.-F. Room-Temperature Synthesis of Soluble, Fluorescent Carbon Nanoparticles from Organogel Precursors. Chem. Commun. 2012, 48, 10144-10146.

(6) Sun, Y.-P.; Zhou, B.; Lin, Y.; Wang, W.; Fernando, K. S.; Pathak, P.; Meziani, M. J.; Harruff, B. A.; Wang, X.; Wang, H. Quantum-Sized Carbon Dots for Bright and Colorful Photoluminescence. J. Am. Chem. Soc. 2006, 128, 7756-7757.

(7) Baker, S. N.; Baker, G. A. Luminescent Carbon Nanodots: Emergent Nanolights. Angew. Chem., Int. Ed. 2010, 49, 6726-6744.

(8) Zheng, M.; Ruan, S.; Liu, S.; Sun, T.; Qu, D.; Zhao, H.; Zhingang, X.; Gao, H.; Jing, X.; Sun, Z. Self-targeting Fluorescent Carbon Dots for Diagnosis of Brain Cancer Cells. ACS Nano 2015, 9, 1145511461.

(9) Yang, S. T.; Cao, L.; Luo, P. G. J.; Lu, F. S.; Wang, X.; Wang, H. F.; Meziani, M. J.; Liu, Y. F.; Qi, G.; Sun, Y. P. Carbon Dots for Optical Imaging in Vivo. J. Am. Chem. Soc. 2009, 131, 11308-11309.

(10) Li, H.; He, X. D.; Kang, Z. H.; Huang, H.; Liu, Y.; Liu, J. L.; Lian, S. Y.; Tsang, C. H. A.; Yang, X. B.; Lee, S. T. Water-Soluble Fluorescent Carbon Quantum Dots and Photocatalyst Design. Angew. Chem., Int. Ed. 2010, 49, 4430-4434.

(11) Cao, L.; Sahu, S.; Anilkumar, P.; Bunker, C. E.; Xu, J.; Fernando, K. A. S.; Wang, P.; Guliants, E. A.; Tackett, K. N.; Sun, Y. P. Carbon Nanoparticles as Visible-Light Photocatalysts for Efficient $\mathrm{CO}_{2}$ Conversion and Beyond. J. Am. Chem. Soc. 2011, 133, 4754-4757.

(12) Shih, C. C.; Chen, P. C.; Lin, G. L.; Wang, C. W.; Chang, H. T. Optical and Electrochemical Applications of Silicon-Carbon Dots/ Silicon Dioxide Nanocomposites. ACS Nano 2015, 9, 312-319.

(13) Li, X.; Zhang, S.; Kulinich, S. A.; Liu, Y.; Zeng, H. Engineering surface states of carbon dots to Achieve Controllable Luminescence for Solid-Luminescent Composites and Sensitive $\mathrm{Be}^{2+}$ Detection. Sci. Rep. 2015, 4, No. 4976.

(14) Chowdhury, D.; Gogoi, N.; Majumdar, G. Fluorescent Carbon Dots Obtained from Chitosan Gel. RSC Adv. 2012, 2, 12156-12159.

(15) Gogoi, N.; Barooah, M.; Majumdar, G.; Chowdhury, D. Carbon Dots Rooted Agarose Hydrogel Hybrid Platform for Optical Detection and Separation of Heavy Metal Ions. ACS Appl. Mater. Interfaces 2015, 7, 3058-3067. 
(16) Gao, X.; Du, C.; Zhuang, Z.; Chen, W. Carbon quantum dotbased nanoprobes for metal ion detection. J. Mater. Chem. C. 2016, 4, 6927-6945.

(17) Zhang, R.; Chen, W. Nitrogen-doped carbon quantum dots: Facile synthesis and application as a "turn-off" fluorescent probe for detection of $\mathrm{Hg}^{2+}$ ions. Biosens. Bioelectron. 2014, 55, 83-90.

(18) Gao, X.; Lu, Y.; Zhang, R.; He, S.; Ju, J.; Liu, M.; Li, L.; Chen, $\mathrm{W}$. One-pot synthesis of carbon nanodots for fluorescence turn-on detection of $\mathrm{Ag}^{+}$based on the $\mathrm{Ag}^{+}$-induced enhancement of fluorescence. J. Mater. Chem. C 2015, 3, 2302-2309.

(19) Ju, J.; Chen, W. Synthesis of highly fluorescent nitrogen-doped graphene quantum dots for sensitive, label-free detection of Fe (III) in aqueous media. Biosens. Bioelectron. 2014, 58, 219-235.

(20) Ju, J.; Chen, W. In Situ Growth of Surfactant-Free Gold Nanoparticles on Nitrogen-Doped Graphene Quantum Dots for Electrochemical Detection of Hydrogen Peroxide in Biological Environments. Anal. Chem. 2015, 87, 1903-1910.

(21) Ju, J.; Zhang, R.; He, S.; Chen, W. Nitrogen-doped graphene quantum dots-based fluorescent probe for the sensitive turn-on detection of glutathione and its cellular imaging. RSC Adv. 2014, 4, 52583-52589.

(22) Gu, J.; Hu, D.; Huang, J.; Huang, X.; Zhang, Q.; Jia, X.; Xi, K. One-Pot Synthesis and Control of Aqueous Soluble and Organic Soluble Carbon Dots from a Designable Waterborne Polyurethane Emulsion. Nanoscale 2016, 8, 3973-3981.

(23) Zheng, B.; Liu, T.; Man Chin Paau, M. C.; Wang, M.; Liu, Y.; Liu, L.; Wu, C.; Du, J.; Xiao, D.; Choi, M. M. F. One Pot Selective Synthesis of Water and Organic Soluble Carbon Dots with Green Fluorescence Emission. RSC Adv. 2015, 5, 11667-11675.

(24) Wang, F.; Xie, Z.; Zhang; Liu, H.; Zhang, C. Y. Highly Luminescent Organosilane-Functionalized Carbon Dots. Adv. Funct. Mater. 2011, 21, 1027-1031.

(25) Suzuki, M.; Owa, S.; Kimura, M.; Kurose, A.; Shiraib, H.; Hanabusa, K. Supramolecular Hydrogels and Organogels based on Novel L-valine and L-isoleucine Amphiphiles. Tetrahedron Lett. 2005, 46, 303-306.

(26) Yang, H.; Yi, T.; Zhou, Z.; Zhou, Y.; Wu, J.; Xu, M.; Li, F.; Huang, C. Switchable Fluorescent Organogels and Mesomorphic Superstructure Based on Naphthalene Derivatives. Langmuir 2007, 23, 8224-8230.

(27) Mukhopadhyay, S.; Maitra, U. Chemistry and Biology of Bile Acids. Curr. Sci. 2004, 87, 1666-1683.

(28) Bhat, S.; Maitra, U. Nanoparticle-Gel Hybrid Material Designed with Bile Acid Analogues. Chem. Mater. 2006, 18, 4224-4226.

(29) Mei, J.; Leung, N. L. C.; Kwok, R. T. K.; Lam, J. W. Y.; Tang, B. Z. Aggregation-Induced Emission: Together We Shine, United We Soar! Chem. Rev. 2015, 115, 11718-11940.

(30) Tang, B. Z.; Zhan, X.; Yu, G.; Sze Lee, P. P.; Liu, Y.; Zhu, D. Efficient Blue Emission from Siloles. J. Mater. Chem. 2001, 11, 29742978.

(31) Mei, J.; Hong, Y.; Lam, J. W. Y.; Qin, A.; Tang, Y.; Tang, B. Z. Aggregation-Induced Emission: The Whole Is More Brilliant than the Parts. Adv. Mater. 2014, 26, 5429-5479.

(32) Hong, Y.; Lam, J. W. Y.; Tang, B. Z. Aggregation-Induced Emission: Phenomenon, Mechanism and Applications. Chem. Commun. 2009, 4332-4353.

(33) Tang, W.; Xiang, Y.; Tong, A. Salicylaldehyde Azines as Fluorophores of Aggregation-Induced Emission Enhancement Characteristics. J. Org. Chem. 2009, 74, 2163-2166.

(34) Luo, J.; Xie, Z.; Lam, J. W. Y.; Cheng, L.; Tang, B. Z.; Chen, H.; Qiu, C.; Kwok, H. S.; Zhan, X.; Liu, Y. Aggregation-Induced Emission of 1-methyl-1,2,3,4,5-pentaphenylsilole. Chem. Commun. 2001, 17401741.

(35) Lu, P.; Lam, J. W. Y.; Liu, J.; Jim, C. K. W.; Yuan, W.; Xie, N.; Zhong, Y.; Hu, Q.; Wong, K. S.; Cheuk, K. K. L. Aggregation-Induced Emission in a Hyperbranched Poly(silylenevinylene) and Superamplification in Its Emission Quenching by Explosives. Macromol. Rapid Commun. 2010, 31, 834-839.
(36) Wang, J.; Mei, J.; Yuan, W.; Lu, P.; Qin, A.; Sun, J.; Ma, Y.; Tang, B. Z. Hyperbranched Polytriazoles with High Molecular Compressibility: Aggregation-Induced Emission and Superamplified Explosive Detection. J. Mater. Chem. 2011, 21, 4056-4059.

(37) Hu, R.; Lam, J. W. Y.; Liu, J.; Sung, H. H. Y.; Williams, I. D.; Yue, Z.; Wong, K. S.; Yuen, M. M. F.; Tang, B. Z. Hyperbranched Conjugated Poly(tetraphenylethene): Synthesis, Aggregation-Induced Emission, Fluorescent Photopatterning, Optical Limiting and Explosive Detection. Polym. Chem. 2012, 3, 1481-1489.

(38) Xu, Y.; Chen, L.; Guo, Z.; Nagai, A.; Jiang, D. Light-Emitting Conjugated Polymers with Microporous Network Architecture: Interweaving Scaffold Promotes Electronic Conjugation, Facilitates Exciton Migration, and Improves Luminescence. J. Am. Chem. Soc. 2011, 133, 17622-17625.

(39) Chen, Q.; Wang, J.-X.; Yang, F.; Zhou, D.; Bian, N.; Zhang, X.J.; Yan, C.-G.; Han, B.-H. Tetraphenylethylene-Based Fuorescent Porous Organic Polymers: Preparation, Gas Sorption Properties and Photoluminescence Properties. J. Mater. Chem. 2011, 21, 1355413560.

(40) Qin, A.; Tang, B. Z. Aggregation-Induced Emission: Fundamentals; Wiley: Singapore, 2014.

(41) Agnihotri, N.; Chowdhury, A. D.; De, A. Non-enzymatic Electrochemical Detection of Cholesterol Using $\beta$-cyclodextrin Functionalized Graphene. Biosens. Bioelectron. 2015, 63, 212-217.

(42) Rasras, A. J.; Al-Telb, T. H.; Al-Aboudia, A. F.; Al-Qawasmeha, R. A. Synthesis and Antimicrobial Activity of Cholic Acid Hydrazone Analogues. Eur. J. Med. Chem. 2010, 45, 2307-2313.

(43) Kitahara, T.; Shirakawa, M.; Kawano, S. I.; Beginn, U.; Fujita, N.; Skinkai, S. Creation of a Mixed-Valence State from OneDimensionally Aligned TTF Utilizing the Self-Assembling Nature of a Low Molecular-Weight Gel. J. Am. Chem. Soc. 2005, 127, 1498014981.

(44) Mourdikoudis, S.; Liz-Marzán, L. M. Oleylamine in Nanoparticle Synthesis. Chem. Mater. 2013, 25, 1465-1476.

(45) Wu, F.; Xu, G.; Zeng, X.; Mu, L.; Redshaw, C.; Wei, G. Characterization of the Aggregation-Induced Enhanced Emission of $\mathrm{N}$, $\mathrm{N}^{\prime}$-bis (4-methoxysalicylide) benzene-1, 4-diamine. J. Fluoresc. 2015, $25,1183-1189$.

(46) An, B. K.; Kwon, S. K.; Jung, S. D.; Park, S. Y. Enhanced Emission and its Switching in Fluorescent Organic Nanoparticles. J. Am. Chem. Soc. 2002, 124, 14410-14415.

(47) Oelkrug, D.; Tompert, A.; Gierschner, J.; Egelhaaf, H.; Hanack, M.; Hohloch, M.; Steinhuber, E. Tuning of Fluorescence in Films and Nanoparticles of Oligophenylenevinylenes. J. Phys. Chem. B 1998, 102, 1902-1907. 